Série des Documents de Travail

\author{
$n^{\circ}$ 2012-10 \\ Native Language, \\ Spoken Language, \\ Translation and Trade \\ J. MELITZ ${ }^{1}$ \\ F. TOUBAL ${ }^{2}$
}

May, 2012

Les documents de travail ne reflètent pas la position du CREST et n'engagent que leurs auteurs. Working papers do not reflect the position of CREST but only the views of the authors.

\footnotetext{
1 Heriot-Watt University, CEPR, CREST and CEPII. Email : j.melitz@hw.ac.uk Address : Department of Economics, Mary Burton Building, Heriot-Watt University, Edinburgh EH14 4AS, UK. 2 Université d'Angers, Paris School of Economics and CEPII. Email : toubal@cepii.fr Address : CEPII, 113 rue de Grenelle, 75007 Paris
} 


\title{
Native Language, Spoken Language, Translation and Trade ${ }^{*}$
}

\author{
Jacques MELITZ ${ }^{\mathrm{a}}$ and Farid TOUBAL ${ }^{\mathrm{b}}$
}

\begin{abstract}
We construct new series for common native language and common spoken language for 195 countries, which we use together with series for common official language and linguistic proximity in order to draw inferences about (1) the aggregate impact of all linguistic factors on bilateral trade, (2) whether the linguistic influences come from ethnicity and trust or ease of communication, and (3) in so far they come from ease of communication, to what extent translation and interpreters play a role. The results show that the impact of linguistic factors, all together, is at least twice as great as the usual dummy variable for common language, resting on official language, would say. In addition, ease of communication is far more important than ethnicity and trust. Further, so far as ease of communication is at work, translation and interpreters are extremely important. Finally, ethnicity and trust come into play largely because of immigrants and their influence is otherwise difficult to detect.
\end{abstract}

JEL Classification : F10; F40

Keywords : Language, Bilateral Trade, Gravity Models

\footnotetext{
* The authors would like to thank Paul Bergin, Mathieu Crozet, Ronald Davies, Peter Egger, Victor Ginsburgh, Thierry Mayer, Marc Melitz, Giovanni Peri, and the members of the economics seminars at CES-Ifo, ETR Zurich, Heriot-Watt University, the Paris School of Economics, the University of California at Davis, UCLA, and University College Dublin for valuable comments.

${ }^{a}$ Heriot-Watt University, CEPR, CREST and CEPII. Email: j.melitz@hw.ac.uk

Address : Department of Economics, Mary Burton Building, Heriot-Watt University, Edinburgh EH14 4AS, UK.

${ }^{\mathbf{b}}$ Université d'Angers, Paris School of Economics and CEPII. Email : toubal@cepii.fr Address : CEPII, 113 rue de Grenelle, 75007 Paris.
} 


\section{Introduction}

It is now customary to control for common language in the study of any influence on bilateral trade, whatever the influence may be. The usual measure of common language is a binary one based on official status. However, it is not obvious that such a measure of common language can adequately reflect the diverse sources of linguistic influence on trade, including ethnic ties and trust, ability to communicate directly, and ability to communicate indirectly through interpreters and translation. In this study we try to estimate the impact of language on bilateral trade from all the likely sources by constructing separate measures of common native language $\mathrm{CNL}$, common spoken language CSL, common official language COL, and linguistic proximity LP between different native languages. The interest of this combination of measures is easy to see. If CSL is significant in the presence of CNL, the significance of CSL would clearly reflect ease of communication rather than ethnicity and trust. The additional importance of COL, in the joint presence of CSL and CNL, would indicate the contribution of institutionalized support for translation from a chosen language into the others that are spoken at home. If LP proves significant while all three previous measures of a common language are present, this might reflect the ease of obtaining translations and interpreters when native languages differ without any public support in a decentralized manner. Or else it might reflect the importance of the degree of ethnic rapport between groups when their native languages differ. Our study, based on all four of the measures together, does indeed cast a lot of light on the total impact of language and the relative contributions of the different sources of linguistic influence.

In the first place, our results reinforce the earlier conclusion of Melitz (2008) that COL underestimates the impact of language at least on the order of one-half. That conclusion had rested on far poorer data. In addition, our results show that any estimate based on a single criterion of a common language, whether it be spoken language, native language or official language, falls far short of the mark. We also establish (as Melitz had taken for granted) that the primary source of linguistic influence on bilateral trade is information rather than ethnicity. At least $2 / 3$ of the influence of language comes from ease of communication alone 
and has nothing to do with ethnic ties or trust. Based on an application of the Rauch (1999) classification between homogeneous, listed and heterogeneous goods, the role of ethnic ties and trust is mainly confined to differentiated goods. This may not be surprising. We would have expected the significance of ethnic ties and trust to be higher for differentiated goods than homogenous ones since the required information for bilateral trade is higher, but confirmation is reassuring. Furthermore, all influence of ethnicity on bilateral trade is primarily attributable to cross-migrants. Once cross-migrants enter the analysis, it is difficult to find any trace of influence of ethnicity for all 3 Rauch categories of goods, including differentiated ones. These results all take into account common religion, common law and the history of wars as well as the variables of long standing in the gravity literature on bilateral trade, that is, distance, contiguity, and two separate measures of ex-colonialism.

Of course, once we allow CSL and second languages to enter in explaining bilateral trade, we open the door to simultaneity bias. In response to this problem, we will propose a measure of common language resting strictly on exogenous factors for use as a control for language in studies of bilateral trade when the focus is not on language but elsewhere. This measure will depend strictly on CNL, COL and LP. However, when the subject is language itself, for example, the trade benefit of acquiring second languages or else the case for promoting second languages through public schooling in order to promote trade, a joint determination of bilateral trade and common language will be required. It will then be necessary to go beyond our work. Notwithstanding, we believe our work to be an essential preliminary for such later investigation. Any effort to determine bilateral trade and common language jointly must capture the main linguistic influences on trade and be able to measure those influences. In addition, the large role of interpreters and translation in trade that we bring to light matters both for empirical analysis and policy. Empirically, this ability of interpreters and translation to facilitate trade makes it easier to understand why some firms are able to cross so many language barriers despite the separate importance of each and every one. As regards policy, the role of interpreters and translation points to social (third-party) effects of bilingualism that individuals may not internalize in their decisions about learning languages. In the closing section we will return to the implications of our study for subsequent empirical work on trade, 
the benefits of learning languages and optimal language policy.

Obviously crucial for our work was an ability to construct separate series for CSL, CNL, COL and LP. Of the four, the only easy series to construct is COL. In this study, as everywhere, this measure is a binary one, either 0 or 1 . We treated the other three linguistic series as continuous ones going from 0 upwards. Of the three, CNL was the easiest one to build. In principle, we could have done so based on a single source, Ethnologue, or perhaps Encyclopedia Britannica (which contains less detailed information) as Alesina et al. (2003) did, though we proceeded differently. However, constructing series for CSL and LP was a considerable challenge.

When one of us tackled the problem of measuring a CSL about a decade ago, the information was so widely dispersed and difficult to get that he decided to stick to two sources in order to retain some degree of consistency and reproducibility, namely, Ethnologue and the CIA world factbook. He also needed to rely heavily on inferences from these two sources concerning literacy rates (Melitz (2008)). When we revisited the problem together more recently, the information was far better and surprisingly easier to collect. Special Eurobarometer 243 (2006) made available the results of a detailed survey in November-December 2005 on spoken languages in all EU members (including the two then-current prospective ones and the two candidate members). Crystal (2005) had updated his earlier estimates of English speakers in many parts of the rest of the world (which had appeared in Crystal (1997)) in the second edition of the Cambridge Encyclopedia of the English Language. In addition, the French Foreign Service supplied estimates of speakers of French for the members of l'organisation de la francophonie. Very helpfully, the editors of the web encyclopedia Wikipedia had started a special project of collecting referenced information on world languages, which incorporated the results of a number of national census reports. Among other things, they had conveniently brought together fairly comprehensive tables for English, Spanish and Portuguese. Finally, the web version of Ethnologue offered far better coverage of second languages (non-native languages) than the earlier published versions. 
In the case of linguistic proximity LP, we were perhaps even luckier. There had been measures of LP relying on scores on tests of language proficiency, usually concerning immigrants and sometimes applicants for academic study abroad. However, all such measures related to English. They had also usually centered on the US (see, for example, Chiswick and Miller $(1998,2004))$. These measures therefore were not ideal for us since we wanted ones applying to as wide as possible a world sample in order to identify four separate linguistic influences simultaneously. ${ }^{1}$ Perhaps the broadest source of quantified information on the subject of LP for years was a study by ethnostatisticians (Dyen et al. (1992)). Yet even this study is too confining for us since it is restricted to indo-European languages. However, a clever effort to overcome this last problem had been made by Laitin (2000) and Fearon (2003) (jointly and earlier in unpublished work) on the basis of the Ethnologue classification of language family trees. This effort had also since been taken up in studies of various topics (see Guiso et al. (2009) and Desmet et al. (2009a, b)). See Ginsburgh and Weber (2011) for a nice general treatment. We had prepared to rely exclusively on this method as well when it became possible to do better.

Ethnolinguists had been trying to unify and systematize knowledge of lexical, grammatical and phonological aspects of languages for decades and not only for the indo-European family group but other language families as well. The advent of the computer permitted this collective effort to make remarkable advances in recent years. At the time that we first learned of the Automated Similarity Judgment Program or ASJP, an international project headed by ethnolinguists and ethnostatisticians dating to the mid-2000s (see Brown et al. (2008)), it had a databank covering the lexical aspects (word meanings) of more than 2400 of the world's nearly 7000 languages (Bakker et al. (2009)). By the time we engaged in an exchange with a prominent member of the project, Dik Bakker, in October 2010, there were

\footnotetext{
${ }^{1}$ There have been two earlier efforts to apply such measures of LP to bilateral trade, both of note, and both of them requiring some limitations that we wished to avoid. In the first (which depended on degrees of English proficiency by emigrants to the US), Hutchison (2005) restricts himself to bilateral trade with the US. In the second, a particularly intriguing effort (based on scores on tests of English proficiency for admission to US colleges), $\mathrm{Ku}$ and Zussman (2010) manage to treat worldwide trade. But to do so they suppose that the single linguistic factor that enters in the analysis of bilateral trade besides "native or official language" (see the note to Table A1) is the ability of English to serve as a go-between.
} 
already "close to 5000" in the databank (to quote him). He had the kindness to supply us the matrix of language distances for virtually all of the 100-some languages we asked for (and even to suggest close substitutes in virtually all the cases where the specific varieties we requested were not the ones to which the group had given priority). Our basic problem then was to convert this language by language matrix to a country by country one for linguistic distances. This was no mean task since we required consideration of 195 countries in our final results; but it did not demand any further research.

The next section contains the basic gravity model of bilateral trade. There we shall explain our controls in order to study language, which as mentioned include common legal system, common religion, and the history of wars since 1823, as well as distance, contiguity, and two measures of ex-colonialism. In the following section, we will discuss our data and explain all of our measures. Section IV shall discuss the econometric specification and our basic reliance on cross-sectional evidence. While we shall use panel estimates for 1998-2007 inclusively, we shall always do so with country-year fixed effects. Therefore the estimates strictly rest on the cross-sectional evidence. In addition, we shall employ the cross-sectional estimates in the 10 individual years to indicate robustness. Since our main analysis deals strictly with positive values for trade, we will also raise the issue of the zeros in the trade data, to which we will return in an appendix. Section V will present our results for trade in the aggregate. Section VI will then study separately each of the three Rauch classifications. Section VII will propose our aforementioned aggregate index of a common language based on exogenous sources. According to this new measure, on a scale of 1 to 100 a one-point increase in common language from all the previous sources increases bilateral trade by 1.15 percent. Estimates based on official status alone would be around 0.5 percent. In terms of the literature, 0.5 corresponds precisely to the estimate in Frankel and Rose (2002) and in Melitz (2008). A recent meta-analysis by Egger and Lassmann (2011), which rests on 81 different studies, reports a coefficient of 0.44 .

In all parts of the preceding analysis, we ignore endogenous influences on bilateral trade apart from spoken language (CSL) since those might depend on language. In section VIII, we will 
then go back to the one of these influences that really matters and modifies the linguistic effects, namely, cross-migrants. (Free trade areas and common currency areas do not matter.) As will be seen, roughly 25 to 38 percent of the influence of linguistic influences on bilateral trade from all sources, informational and cultural, comes from cross-migrants. Perhaps part of this influence of cross-migrants is independent of language. But isolating this part would be a separate project. The evidence also plainly shows that cross-migrants are the main reason for the role of ethnicity and trust in explaining linguistic influences on bilateral trade. In addition, our work assumes that the particular language does not matter for the results. Section IX will examine this assumption for English. We find no separate role for this language, nor for any of the other major world ones. Section $\mathrm{X}$ will contain a concluding discussion.

\section{Theory}

We shall use the gravity model in our study with a single minor adaptation: namely, to treat the differences in prices on delivery (cif) from different countries as stemming either from trade frictions, as is usually done, or else from Armington (1969) preferences for trade with different countries. This will allow for the possibility that the influence of common language reflects a choice of trade partners as such rather than trade frictions. The basic equation, which remains founded on CES preferences in all countries, is:

$$
M_{i j}=\left(\frac{t_{i j} p_{j}}{P_{i}}\right)^{1-\beta} \frac{Y_{i} Y_{j}}{Y_{w}}
$$

$M_{i j}$ is the trade flow from country $j$ to country $i . Y_{i}$ and $Y_{j}$ are the respective incomes of the importing and exporting countries and $\mathrm{Y}_{\mathrm{W}}$ is world output. $\beta$ is the elasticity of substitution between different goods and greater than $1 . \mathrm{P}_{\mathrm{i}}$ is the Dixit-Stiglitz price level (based on utility maximization) of the importing country and $\mathrm{p}_{\mathrm{j}}$ is the price of country $\mathrm{j}$ exports. $\mathrm{t}_{\mathrm{ij}}$ is $1+\mathrm{x}_{\mathrm{ij}}$ where as a fundamental point, $\mathrm{x}_{\mathrm{ij}}$ is either positive and stands for the percentage of the costs of foreign trade attributable to trade frictions relative to the export price $\mathrm{p}_{\mathrm{j}}$, or is negative and stands for the percentage discount below $p_{j}$ that country $j$ 's firms accord country $i$ out of ethnic tie or trust. The $\mathrm{M}_{\mathrm{ji}}$ equation is the same with $\mathrm{t}_{\mathrm{ji}} \mathrm{p}_{\mathrm{i}} / \mathrm{P}_{\mathrm{j}}$ instead.

We shall be interested strictly in the sum impact of language on trade and not the difference 
between fixed costs and variable costs of language. Otherwise, the instances of zero bilateral trade would have special significance, as Helpman et al. (2008) have shown. We will also not concern ourselves with the symmetry of the respective impacts of linguistic influences on imports in the two opposite directions for a country pair. Recent work would imply that the linguistic effects reflecting trust between country pairs are notably asymmetric (see Guiso et al. (2009) and Felbermayr and Toubal (2010)). We shall disregard the point.

Next, we propose to model $\mathrm{t}_{\mathrm{ij}}$ in a convenient log-linear form, namely

$$
\mathrm{t}_{\mathrm{ij}}=\mathrm{D}^{\gamma_{1}} \times \exp \left(\sum_{\mathrm{k}=2}^{\mathrm{n}} \gamma_{\mathrm{k}} \mathrm{v}_{\mathrm{ij}, \mathrm{k}}\right)
$$

where $\mathrm{D}$ is bilateral distance and the $\mathrm{v}_{\mathrm{ij}}$ terms are bilateral frictions or aids to trade. Accordingly, $\gamma_{1}$ is an elasticity and $\left[\gamma_{\mathrm{k}}\right]_{\mathrm{k}}=2, \ldots, \mathrm{n}$ is a vector of semi-elasticities. Except for 2 cases that we will explain in due course, all of the $\mathrm{v}_{\mathrm{ij}}$ terms are either 0,1 dummies or else continuous $0-1$ values going from 0 to 1 .

COL, CSL, CNL, and LP will be separate $v_{\mathrm{ij}}$ terms. Melitz (2008) interprets the dummy or 0,1 character of COL as implying that status as an official language means that all messages in the language are received by everyone in the country at no marginal cost, regardless what language they speak. There is an overhead social cost of establishing an official language and therefore a maximum of two languages with official status in accord with the literature. But once a language is official, receiving messages that originate in this language requires no private cost, overhead or otherwise: everyone is "hooked up." Here we shall follow this view except on one important point. For reasons that will emerge later, we will consider the presence of a private once-and-for-all overhead cost of getting "hooked up". This leads us to abandon the reference to "open-circuit communication". As always, if COL equals 1 a country pair shares an official language and otherwise COL equals 0.

CSL is a probability (0-1) that a pair of people at random from the two countries understand one another in some language. CNL is the $0-1$ probability that a random pair from two countries speak the same native language. Therefore CSL embraces CNL and is necessarily equal or greater than CNL. LP refers to the closeness of two different native languages along 
a purely lexical scale, where a rise in LP means greater closeness. As a fundamental point, LP is therefore irrelevant when two native languages are identical. For that reason, we never entertain LP as a factor when CNL is 1 and assign it a value of 0 in this case as well as when two languages bear no resemblance to one another whatever. In principle, we might have assigned LP a value of 1 rather than 0 when CNL is 1 and simply constructed a combined $0-1$ CNL+LP variable with LP adding something to the probability of communication in encounters between people when their native languages differ. However, our measure of LP rests on a completely different scale than the one for CNL. Furthermore, we wanted to distinguish the issue of translation and ability to interpret from that of direct communication. For these reasons, we prefer to estimate the two influences separately (in a manner that we shall discuss) and assign separate coefficients to them though we shall try to combine them eventually. $^{2}$

The additional $\mathrm{v}_{\mathrm{ij}}$ terms are required controls in order to discern the impact of linguistic ties on bilateral trade. Countries with a common border often share a common language. PreWWII colonial history in the twentieth century and earlier is also highly important. People in ex-colonies of an ex-colonizer often know the language of the ex-colonizer and, as a result, people in two ex-colonies of the same ex-colonizer will also tend to know the ex-colonizer's language. We therefore use dummies for common border, relations between ex-colonies and ex-colonizer and relations between pairs of ex-colonies of the same ex-colonizer as additional $\mathrm{V}_{\mathrm{ij}}$ terms and we base ex-colonial relationships on the situation in 1939, at the start of WWII. ${ }^{3}$

In addition, we wanted to reflect some additional variables that have entered the gravity literature more recently and could well interact with the linguistic variables. These are common legal system, common religion, and trust (apart from whatever indication of trust a CL provides). A common legal system affects the costs of engaging in contracts, a consideration not unlike the costs of misunderstanding that result from different languages. A

\footnotetext{
${ }^{2}$ When we do combine the two, we also render the series for LP comparable (at the means) to the one for COL, the other linguistic series that refers to translation.

${ }^{3}$ Common country also sometimes enters as a variable in gravity models because of separate entries for overseas territories of countries (e.g., France and Guadeloupe). Our database does not include these overseas regions separately (e.g., Guadeloupe is included in France).
} 
common religion creates affinities and trust between people just as a CNL might. On such reasoning, we added a 0,1 dummy for common legal system, and created a continuous 0-1 variable for common religion on all fours with the one for CNL. Quite specifically, our common religion variable refers to the probability that two people at random from two countries share the same religion. To reflect trust as distinct from native language, was a particular problem. Guiso et al. (2009) had exploited survey evidence about trust as such in an EU survey of EU members. We have no such possibility in our worldwide sample. They also used genetic distance and somatic distance to reflect ancestral links between people. However, no one has yet converted these indices into worldwide ones for all country pairs. ${ }^{4}$ The only measure of ancestral links of theirs that we were able to use readily is the history of wars; or at least we could do so by limiting ourselves to wars since 1823 rather than 1500 as they had. This more limited measure of ancestral conflicts, it should be noted, has already proven useful in related work concerning civil wars by Sarkees and Wayman (2010) (to say nothing of related work by Martin et al. (2008) where the civil war data starts only in 1950).

As mentioned earlier, we decided to exclude possible controls that might be affected by bilateral trade itself in our study period and therefore might be endogenous. For this reason, we omitted free trade agreements (FTAs), common currency areas and cross-migration. ${ }^{5}$ The problem in all of these cases is easy to see. Suppose, for example, that by promoting bilateral trade, a CL enhances FTAs. Introducing FTAs as a separate control in the analysis may then mask some influence of CL on trade. Of course, if FTAs affect trade independently of language and are positively or negatively correlated with language, excluding FTAs will entail some omitted variable bias. For this reason, we shall need to check later on whether adding FTAs, common currency areas and cross-migration affects our estimates of the impact

\footnotetext{
${ }^{4}$ In a related study to that of Guiso et al. (2009), Giuliano et al. (2006) also limited their use of genetic and somatic indices to Europe.

5 As regards FTAs and common currency areas, Baier and Bergstrand (2007), and more recently Egger et al. (2011), show a powerful reciprocal influence between FTAs and bilateral trade. Similarly, Persson (2001) argues that common currency areas may be endogenous (though see Rose's (2001) response). Further, earlier studies give strong reason to think that cross-migration hinges partly on bilateral trade even if the work thus far has tended to concentrate on the impact the other way, that is, that of emigrants on trade.
} 
of language on trade. Only cross-migration does so, as presaged earlier, and we shall examine the implications. Still, if only for clarity, we prefer estimating the impact of linguistic influences in the absence of any endogenous variables except CSL in our main investigation.

\section{Data and measures}

Regarding data and measures, our source for bilateral trade is the BACI database of CEPII, which corrects for various inconsistencies (see Gaulier and Zignano (2010)). The series concerns 224 countries in 1998 to 2007 inclusively, of which 29 (mostly tiny islands) drop out because of missing information on religion, legal framework and/or the share of native and spoken languages. Eventually, we also dropped all observations that do not fit into Rauch's tripartite classification (as the BACI database permits us to do). This last limitation meant losing only a minor additional percentage of the remaining observations, less than 0.5 of one percent. Our measure of distance rests on the 2 most populated cities and comes from the CEPII database as well. We shall concentrate next on our four language variables.

\section{(a) Common official language}

With regard to COL, the usual source is the CIA World Factbook. Though we used it as well, we considered the broader evidence. As an example of the insufficiency of the Factbook, English was adopted as an official language in Sudan only in 2005, during our study period, while Russian was adopted officially in Tajikistan in 2009, since our study period. However, in Tajikistan, Russian had continued to be widely used uninterruptedly in government and the media since the breakdown of the Soviet Union in 1990, whereas there is no reason to believe that the decision of Sudan to adopt English was independent of trade in our study period. Similarly, in some countries, though the language of the former colonial ruler was dropped officially after national independence, it remained in wide use in government and the media throughout. This pertains to French in Algeria, Morocco and Tunisia. Other issues arose. Thus, Lebanon has a law specifying situations where French may be used officially. German is official in some neighboring regions of Denmark. In the case of all such questions, we tended toward a liberal interpretation on the grounds that the basic issue was public support for the language through government auspices. Thus, we accepted German in Denmark, 
Russian in Tajikistan, French in Lebanon, Algeria, Morocco and Tunisia. Finally, we restricted ourselves, as is typically done, to 2 official languages at most. To do so, we kept the 2 most important languages in world trade. Because of this 2-language restriction, we kept English and Chinese for Singapore but dropped Malay, which is also rather important in the region (a problematic case). As a result of this exercise, all in all, we have 19 official languages (only 19 since a language must be official in at least 2 countries in order to count). These languages are listed in Table 1.

\section{(b) Common spoken language}

With regard to CSL, we required all languages to be spoken by at least $4 \%$ of the population in 2 countries (as in Melitz (2008)). Lower ratios would have expanded the work greatly without affecting the results. The outcome is a total of 42 CSL languages, including all the 19 COL ones. In identifying these 42 languages, we equated Tajik and Persian (Farsi); Afrikaner and Dutch; Macedonian and Bulgarian; Turkmen, Azerbaijani, and Turkish; Icelandic and Danish; and Belarusian and Russian. In light of the 4\% minimum, it is important to note that some large world languages fall out of our list, including Japanese and Korean (we neglected North and South). Wherever languages qualified, we also recorded data down to $1 \%$ where we found it (though this does not affect our results). The additional 23 CSL languages besides the COL ones are also listed in Table 1.

\section{Table 1: Common languages}

\begin{tabular}{llll}
\hline Official, spoken and native languages & \multicolumn{2}{l}{ Other spoken and native languages } \\
\hline Arabic & Portuguese & Albanian & Javanese \\
Bulgarian & Romanian & Armenian & Lingala \\
Chinese & Russian & Bengali & Nepali \\
Danish & Spanish & Bosnian & Pashto \\
Dutch & Swahili & Croatian & Polish \\
English & Swedish & Czech & Quechua \\
French & Turkish & Fang & Serbian \\
German & & Finnish & Tamil \\
Greek & & Fulfulde & Ukrainian \\
Italian & & Hausa & Urdu \\
Malay & & Hindi & Uzbek \\
Persian (Farsi) & & Hungarian & \\
\hline
\end{tabular}


With respect to the figures themselves, we used the data from the EU survey in NovemberDecember 2005 (Special Eurobarometer 243 (2006)). This data covers the current 27 EU members (which only numbered 25 at the time) plus Croatia and Turkey, the two applicants. The survey includes 32 languages, 21 of which are part of our CSL list. In recording this data we summed the percentage responses to the two following questions: "What is your maternal language" and "Which languages do you speak well enough in order to be able to have a conversation, excluding your mother tongue (... multiple answers possible)." Next, for English, we used the "list of countries by English-speaking population" from Wikipedia (downloaded 18 June 2010), which reproduces the same numbers that we had extracted from the EU survey but also updates many of the estimates in Crystal (2005) for the rest of the world on the basis of various national census reports and more recent sources. For French, we relied on the "estimation du nombre de francophones dans le monde en 2005" [estimate of the number of francophones in the world] of the organisation internationale de la francophonie (available on the web), which we complemented with information from separate entries for "African French" and for "French Language" in Wikipedia, all the figures for which come from referenced French governmental sources. For Spanish, we used a long entry on "Spanish Language" in Wikipedia offering world figures from numerous cited sources (mostly Ethnologue, national censuses and Encarta). A similar entry for "Geographical distribution of Portuguese" served for Portuguese.

For all the rest, we basically combed the information in Ethnologue on the web first by language and next by country. German, Russian and Arabic deserve separate mention. In the case of German, the entry "Ethnologue: Germany" is particularly useful. So is a Wikipedia entry on "German as a minority language." In the case of Russian, a Gallup poll took place in 2008 with the web entry "Russian language enjoying a boost in post-Soviet states." Arabic was a problem. Despite all of the information in Ethnologue classified by language and by country, we still needed to make numerous inferences from literacy rates in Arab-speaking countries. Our resulting data set covers observations for spoken languages for different years, all between 2000 and 2008. In light of the rapid ascension of English as a world language in 
our study period, we suspect the main flaws in our series to be some of the zeros for spoken English (for example, South Korea).

After the data collection, it was necessary to go from the national data to country pair data. This meant calculating the sums of the products of the population shares that speak identical languages by country pair. Some double-counting took place. Consider simply the fact that the 2005 EU survey allows respondents to quote as many as 3 languages besides their native one in which they can converse. A Dutch and Belgian pair who can communicate in Dutch or German and perhaps also in French may then count 2 or 3 times in our summation. There are indeed 34 cases of values greater than 1 following the summation or the first step in our construction of CSL from the national language data.

In order to correct for this problem, we applied a uniform algorithm to all of the data. Let the aforementioned sum of products or the unadjusted value of a common spoken language be $\alpha_{\mathrm{ij}}$ where $\alpha_{i j}=\sum_{1}^{n} L_{1 i} L_{1 j}$ for country pair ij, $L_{1}$ is a particular language and $n$ is the number of languages the countries share. The algorithm requires first identifying the language that contributes most to $\alpha_{\mathrm{ij}}$, recording its contribution, or $\max \left(\alpha_{\mathrm{ij}}\right)$, which is necessarily equal or less than 1 , and then calculating

$\mathrm{CSL}=\max (\alpha)+(\alpha-\max (\alpha))(1-\max (\alpha))$

(where we drop the country subscripts without ambiguity). CSL is now the adjusted value of $\alpha$ that we will use. In the aforementioned 34 cases of $\alpha$ greater than 1 (whose maximum value is 1.645 for the Netherlands and Belgium-Luxembourg), $\alpha-\max (\alpha)$ is always less than 1 . Therefore the algorithm assures that CSL is 1 and below. ${ }^{6}$ In the other cases, whenever $\alpha$ is close to $\max (\alpha)$, the adjustment is negligible and CSL virtually equals $\max (\alpha)$. However, if $\alpha$ is notably above $\max (\alpha)$, there can be a non-negligible downward adjustment and this adjustment will be all the higher if the values of $\max (\alpha)$ are higher or closer to 1 . This makes sense since values of $\max (\alpha)$ closer to 1 leave less room for 2 people from 2 different

\footnotetext{
${ }^{6}$ The lowest value of CSL in these 34 cases is .75 and relates to Switzerland and Denmark, for which the unadjusted value $\alpha$ is 1.01 . This CSL value implies 1 chance out of 4 that a Dane and a Swiss at random will not understand each other in any language and about the same chance (since $\alpha-$ CSL is .26) that they will understand each other in 2 languages or more.
} 
countries to understand each other only in a different language than the one already included in $\max (\alpha)$. We checked and found that the estimates of the influence of CNL on bilateral trade following the application of the algorithm raise the coefficient of CNL notably without changing the standard error in our estimates. This is exactly the desired result since it signifies that the adjustment eliminates a part of $\alpha$ that has no effect on bilateral trade (doublecounting). We see no simpler way of making the adjustment.

\section{(c) Common native language}

For CNL we favored figures that are consistent with CSL. Thus, we stuck to Special Eurobarometer 243 (2006) for the 29 countries in the EU survey and for the rest, we relied on information from the identical source that we used for CSL whenever possible (not always). In cases where holes needed to be filled we systematically consulted Ethnologue and checked against the CIA World Factbook (which offers detailed breakdowns for some countries but not others). ${ }^{7}$ By and large, we gave preference to dates corresponding to those for CSL. After assembling this data, we summed the products of the percentages of native speakers of common languages by country pair in the same manner as we had for CSL. But in this case, no values greater than one arose (though they could have since the EU survey invites respondents to mention more than one maternal language if they consider that right). In general, double-counting appears negligible in our calculation of CNL and no adjustment was needed. All CSL languages figure in the calculation of CNL. ${ }^{8}$

\section{(d) Linguistic proximity}

The LP measure raises distinct issues. In this case, taking the native language into account is at the heart of the matter regardless whether the language has any role outside the country. Thus, Japanese and Korean figure and, for example, Tagalog is far more relevant than English in the Philippines. In addition, since we needed to simplify, we only admitted 2 native languages at most in calculating LP. When there are 2, we adjusted their relative percentages

\footnotetext{
${ }^{7}$ Even in the cases outside the EU survey where no holes needed to be filled, Ethnologue might well have been the source.

${ }^{8}$ This need not have happened. If any CSL language had failed to be a native language in more than a single country (even at the 1 percent level), it would have fallen out of the CNL group. No such case arose.
} 
to sum to 1 , the same score we ascribed in case of a single native language. Thus, Switzerland shows 0.74 for German and 0.26 for French, Bolivia 0.54 for Spanish and 0.46 for Quechua. The minimum percentage we recorded for a native language was 0.13 for Russian in Israel. Very significantly too, we assigned 31 zeros. Those are cases of countries with a high index of linguistic diversity (in Ethnologue) and where no native language concerns a majority of the population. The underlying logic is clear. When languages are widely dispersed at home, the linguistic benefit of trading at home rather than abroad is muddy to begin with. Therefore, it is questionable to make fine distinctions about the distances of the 2 principal native languages to foreign languages. The 31 countries to which we assigned zeros notably include India (where linguistic diversity scores 0.94 out of 1 ). The other examples are mostly African ones: South Africa is an outstanding case. Following this exercise, we have exactly 89 native languages to deal with. These 89 exclude 5 of the 42 CSP languages (Fang, Fulfulde, Hausa, Lingala and Urdu) for various reasons (an insufficient percentage of native speakers, excessive linguistic diversity or both).

Next, as already presaged, we constructed two separate measures of LP, LP1 and LP2. LP1 is inspired by the aforementioned idea in Fearon (2003) and Laitin (2000) of calculating linguistic proximities on the basis of the Ethnologue classification of language trees between trees, branches and sub-branches. We allowed 4 possibilities, 0 for 2 languages belonging to separate family trees, 0.25 for 2 languages belonging to different branches of the same family tree (English and French), 0.50 for 2 languages belonging to the same branch (English and German), and 0.75 for 2 languages belonging to the same sub-branch (German and Dutch). This methodology poses a problem for comparisons between different trees: for example, it assumes that 0.5 means the same in the Indo-European group as in the Altaic, Turkic one. We held down the number of distinctions within trees to 3 precisely because of uneasiness about this assumption (Fearon (2003) offers a more sophisticated suggestion). However, we also knew at a certain point in our study that we would be able to test whether so crude a method would yield comparable results to those that follow from the more sophisticated measure LP2, resting on the databank of the ASJP (it did). 
As regards LP2, the source is an analysis of lexical similarity between 200 words (sometimes 100) in a list (or two lists) that was (were) first compiled by Swadesh (1952). The members of the ASJP project have since found that a selection of 40 of these words is fully adequate. (See the list in Bakker et al. (2009) or Holman et al. (2008)). In order to construct our numbers, we used the ASJP group's preferred measure which makes an adjustment for noise (the fact that words with identical meaning can resemble each other by chance). The adjusted series go from 0 to 105 rather than 0 to 1 . So we multiplied all the data by $100 / 105$ to normalize the data at 0 to 100 . The original series also signify linguistic distance instead of linguistic proximity, while we prefer the latter, if nothing else because we want all the expected signs of the linguistic variables in the estimates to be the same. Therefore, we took the reciprocal of each figure and we multiplied it by the lowest number in the original series (9.92 for SerboCroatian and Croatian, or the 2 closest languages in the series). This then inverted the order of the numbers without touching the sign while converting the series from $0-100$ to $0-1$.

Once we had made these adjustments to our two 89 by 88 bilateral matrices for linguistic proximity by language, we needed to convert the 2 matrices into country by country ones. We then faced instances of 2 or 4 linguistic proximities for many country pairs, and we needed to construct an appropriate weighted average, which we based on the products of the population ratios of the native speakers in both countries. ${ }^{9}$

After constructing both LP1 and LP2, we normalized both series once more so that their averages for the positive values of LP2 in our sample estimates would equal exactly 1 . This last normalization makes the estimated values of their coefficients exactly comparable to one another and exactly comparable to the coefficient of COL. Making the coefficients of LP comparable to those of COL makes sense since both variables concern translation. The normalization also means that individual values of LP1 and LP2 now go from 0 to more than

\footnotetext{
${ }^{9}$ In some cases 1 or both of the languages in both countries were the same and yet 1 or 2 linguistic proximity or proximities needed to be considered. In those cases we made sure that the population weights of the identical languages were taken into account and that the population weights for the linguistic proximity or proximities (between the 1 or 2 different languages) added up to the right fraction of 1 . Remember that a LP of 0 between 2 countries can mean either that the 2 countries speak the same language - and therefore LP is irrelevant - or that their languages are so different that there is no proximity between them.
} 
We provide all of the raw language data in our dataset for values equal or above .04 on a country basis for all 195 countries in our study in Appendix 1.

\section{(e) The controls}

The controls in the gravity equation demand our attention next. Both of our colonial variables come from Head et al. (2010). For common legal system, we went to the website of JuriGlobe. Specifically, we assigned 1 to all country pairs that shared Civil law, Common law, or Muslim law and 0 to all the rest. Thus, we treated all countries with a Mixed legal system (often including Customary law) as not sharing a legal system with anyone.

With respect to common religion, our starting point was the CIA World Factbook, which reports population shares for Buddhist, Christian, Hindu, Jewish and Muslim, and a residual population share of "atheists." Next, we broke down the Christian and Muslim shares into finer distinctions. For Christians, we distinguished between Roman Catholic, Catholic Orthodox, and Protestants, as the CIA Factbook allows except for 15 countries in our sample, mostly African ones and also China. In these cases, we retrieved the added information either from the International Religious Freedom Report (2007) or the World Christian Database (2005). For Muslim, we distinguished between Shia and Sunni. To do so, we used the Pew Forum (2009) whenever the CIA Factbook did not suffice. In order to construct common religion in the final step, we went ahead exactly as we had for CNL and summed the products of population shares with the same religion. Ours is a more detailed measure of common religion than we have seen elsewhere. ${ }^{10}$

As regards the years of war since 1823, we relied on the Correlates of War Project (COW, v4.0), the data for which is available at http://www.correlatesofwar.org/ and goes up to 2003 . This meant identifying former states of Germany with Germany, identifying the Kingdom of

\footnotetext{
${ }^{10}$ There are two recent studies that analyze the effects of adherence to different major world religions (e.g., Muslim) on bilateral trade and that contain some sophisticated measures of common religion as well: Helble (2007) and Lewer and Van den Berg (2007). In both articles, the authors control for common language with a binary variable (based on one of the usual sources, the popular Haveman website in Helble's case, the CIA Factbook in Lewer and Van den Berg's).
} 
Naples and Sicily with Italy, and substituting Russia for USSR. The series for the number of years at war goes from 0 to 17.

For the stock of migrants, we utilized the World Bank International Bilateral Migration Stock database which is available for 226 countries and territories. It is described in detail in Parsons et al. (2007).

\section{The econometric form}

We estimate two equation forms: one for the cross-sections in the individual years 1998 through 2007; the other for the panel over the 10-year period. The only difference is that in the panel form we use country-year fixed effects instead of country fixed effects. After loglinearizing eq. (1) (following substitution of eq. (2) for $t_{i j}$ ), the form for the individual-year cross-sections is:

$\log \mathrm{M}_{\mathrm{ij}}=\alpha_{\mathrm{o}}+\delta_{\mathrm{c}} \mathrm{Z}_{\mathrm{c}}+\alpha_{1} \mathrm{COL}_{\mathrm{ij}}+\alpha_{2} \mathrm{CSL}_{\mathrm{ij}}+\alpha_{3} \mathrm{CNL}_{\mathrm{ij}}+\alpha_{4} \mathrm{LP}_{\mathrm{ij}}+\alpha_{5} \log \mathrm{D}+\alpha_{6}$ Adjacency $_{\mathrm{ij}}+\alpha_{7}$ Excol $_{\mathrm{ij}}+\alpha_{8}$ Comcol $_{\mathrm{ij}}+\alpha_{9}$ Comleg $_{\mathrm{ij}}+\alpha_{10}$ Comrel $_{\mathrm{ij}}+\alpha_{11}$ Histwars $_{\mathrm{ij}}+\varepsilon_{\mathrm{ij}}$

$\alpha_{\mathrm{o}}$ is a constant that encompasses $\mathrm{Y}_{\mathrm{W}} . \delta_{\mathrm{c}} \mathrm{Z}_{\mathrm{c}}$ is a set of country fixed effects which will reflect all country-specific unobserved characteristics in addition to $Y_{i}, Y_{j}, P_{i}$ and $p_{j} . \delta_{c}$ represents the effects themselves while $Z_{c}$ is a vector of indicator variables (one per country) where $Z_{c}$ equals one if $\mathrm{c}=\mathrm{i}$ or $\mathrm{j}$ and is 0 otherwise. The coefficients $\alpha_{\mathrm{i}}, \mathrm{i}=1, \ldots, 11$, are products of separate bilateral influences on $t_{\mathrm{ij}}$, on the one hand, and $1-\beta$, on the other, where $1-\beta$ is the common negative effect of the elasticity of substitution between goods (since $\beta>1$ ). The disturbance term, $\varepsilon_{\mathrm{ij}}$, is assumed to be log-normally distributed.

As a result of the logarithmic specification, we lose all observations of zero bilateral trade. The principal problem with this elimination of the zeros is a possible selection bias. Imagine that linguistic factors had no role in explaining the cases of the zeros and operated only in the instances of positive trade. Then we might find important linguistic influences in our estimates strictly because of our automatic dropping of the zeros resulting from our choice of equation form. We focus on this issue in the last appendix. 
There are some instances of zero trade in one direction but not the other in our sample. Except for these cases, we have two separate positive observations for imports by individual country pair. Therefore we adjust the standard errors upward for clustering by country pairs in the panel estimates.

\section{The results for total trade}

We turn to the results and begin with the correlation matrix for the separate COL, CSL, CNL and LP series over the 209,276 observations in 1998-2007 in the panel estimates. (The matrices for the individual years can only differ because of minor sample differences and they are virtually identical.) As seen from Table 2, the correlation between COL and either CSL or CNL is well below 1 and only moderately above 0.5 . The outstanding reason is that there are many countries where domestic linguistic diversity is high and the official language (or both of them if there are 2) is (are) not widely spoken. In addition, the correlation between CSL and CNL is only 0.68 and significantly below 1 . In this case the reason is that European languages and Arabic are important as second languages in the world, especially English. LP1 (language tree) and LP2 (ASJP) are highly correlated with one another at 0.84, just as we would expect. They are also both moderately negatively correlated with CNL and positively correlated with CSL. Their negative correlation with CNL is probably due essentially to the fact that their positive values depend on positive values of 1-CNL. Their positive - and more interesting - correlation with CSL probably reflects the fact that higher values of either make a foreign language easier to learn. If we put the two previous opposite correlations together, we can deduce from Table 2 that there is a 0.25 positive correlation between spoken nonnative languages and LP1 and a 0.28 positive correlation between spoken non-native languages and LP2.

Table 2: Correlation Table (195 countries and 209,276 observations)

\begin{tabular}{llllll}
\hline & $\begin{array}{l}\text { Common } \\
\text { official } \\
\text { language }\end{array}$ & $\begin{array}{l}\text { Common } \\
\text { spoken } \\
\text { language }\end{array}$ & $\begin{array}{l}\text { Common } \\
\text { native } \\
\text { language }\end{array}$ & $\begin{array}{l}\text { Linguistic } \\
\text { proximity } \\
\text { (tree) }\end{array}$ & $\begin{array}{l}\text { Linguistic } \\
\text { proximity } \\
\text { (ASPJ) }\end{array}$ \\
\hline Common official language & 1.0000 & & & & \\
Common spoken language & 0.5587 & 1.0000 & & & \\
Common native language & 0.5399 & 0.6791 & 1.0000 & &
\end{tabular}


$\begin{array}{lllll}\text { Linguistic proximity (tree) } & -0.1634 & 0.1489 & -0.0980 & 1.0000\end{array}$

$\begin{array}{llllll}\text { Linguistic proximity (ASPJ) } & -0.2284 & 0.1173 & -0.1586 & 0.8384 & 1.0000\end{array}$

Next, Table 3 presents our basic results for bilateral trade in the aggregate in the panel estimates. In the first 3 columns we show what happens when we introduce COL, CSL or CNL alternatively by itself. Each of the three performs extremely well. But the coefficient of COL is substantially lower than the other two. In addition, since CSL incorporates CNL and we can hardly suppose that a common learned second-language damages bilateral trade, the lower coefficient of CSL than CNL probably signifies simultaneity bias, or the reciprocal positive effect of bilateral trade on language learning. It follows, on this interpretation, that the semi-elasticity of influence of bilateral trade on language learning is at least 0.08 (that is, $0.86-0.78$ ). However, if learned languages (not only native languages) promote trade, the true influence of CSL on bilateral trade is higher than CNL's (or higher than 0.86). Therefore, the simultaneity bias is greater than 0.08 .

The next estimate, column 4, is basically a dialogue with the literature. The early works introducing a 0,1 dummy for common languages in gravity models considered the relevant languages - whether English, Spanish, Arabic, etc. - self-evident and never explained the relevant concept or cited sources. See Havrylyshin and Pritchett (1991), Foroutan and Pritchett (1993), Frankel, Stein and Wei (1993) and Frankel (1997). The practice has never really disappeared. In their influential discussion of trade costs, Anderson and van Wincoop (2004) base their estimates of linguistic barriers to trade entirely on two works that follow the identical practice, namely Eaton and Kortum (2002) and Hummels (2001). One major website for international trade data, associated with Jon Haveman, continues to provide language data under the sub-heading "Languages - lists the primary language for 178 countries" (under the more general heading "useful gravity data") without explaining the grounds for the choice. In all of these cases, it would be unfair to assume that the sole criterion is official status. It could be native language instead or as well. But it must be one or the other or both since the variable is always supposed to be exogenous. The first explicit reference to official status as the strict basis for a dummy variable for a CL that we found is Rose (2000). Rose's initiative took off, especially since 2004-2005. But there has never been any conscious shift in the 
conception of CL. That is the purpose of the 0,1 index of a common language in column 4: to show that a dummy for CL based on a CNL is quite different than one based on a COL and yields different results.

Suppose we constructed a dummy for common language based on native language alone, say on the condition that half or more of the population in both countries possesses the same native language. In our calculation, this would mean basing the index on a CNL of 0.25 or more. The estimate in column 4 shows what happens when we assign a value of 1 to $\mathrm{CL}$ if $\mathrm{CNL} \geq 0.25$. Very significantly, though, this cutoff point is of little importance. We have experimented with cutoff points of 0.1 to 0.7 and the results barely change. As can be seen from column 4, the dummy for CL based on native language has a significantly higher coefficient than COL's, which veers toward CNL's. This veering is even greater in samples with fewer small languages than ours (as seen in the last appendix).

Column 5 proceeds to include COL, CSL and CNL all at once. The coefficients of the 3 notably drop below their earlier values in columns $1-3$, a clear indication that each variable, if standing alone, partly reflects the other two. However, while COL and CSL remain extremely important in column 5, CNL becomes totally insignificant. Instead of pausing on this last result, let us move on to columns 6 and 7 where we introduce LP1 and LP2 as alternatives. Both indicators of LP have identical coefficients of $0.07 / 0.08$ and both are precisely estimated, LP1 more so than LP2. However, when either indicator is present, the coefficient of $\mathrm{CNL}$ rises and becomes significant at the 5\% confidence level. On this evidence, the importance of native language only emerges once we recognize gradations in linguistic proximity between different native languages and we cease to suppose a sharp cleavage between presence and absence of a CNL. In addition, based on columns 6 and 7, all four aspects of CL appear as simultaneously important. Furthermore, the importance of spoken language clearly dominates that of native language. ${ }^{11}$ Last, official status matters independently of anything else.

\footnotetext{
${ }^{11}$ Note that Ku and Zussman's (2010) evidence basically agrees. These authors simply recognize no other spoken language outside of native languages except English.
} 
For the remainder of our study, we will stick to LP2 even though the estimate of LP1 is more precise than LP2 in Table 3. This greater precision is not robust. In earlier experiments with minor differences in the sample, we found the relative precision of LP1 and LP2 to vary and to go sometimes in favor of LP2. Fundamentally, LP2 seems to us better founded and a better basis for reasoning and our later experiments. We shall skip discussion of column 8 until an appropriate later point.

The following table, 4 , repeats the cross-sectional estimates of columns 5 and 7 of Table 3 for the individual years. In this case, we only present estimates for alternative years since that suffices to give the whole picture. As we can see, the robustness is high. The same pattern of changes in the coefficients of COL, CSL and CNL that we found in Table 3 emerges once again. When LP is added, COL and CNL go up, markedly so for CNL, while CSL drops. However, the performance of CNL is uneven across the individual years. We shall return to this last point.

Of some interest as well, Common religion, Common legal system and Years at war are all significant and with the expected signs both in the full sample and in the individual years. Their coefficients are also fairly stable from year to year. There may be some qualification for Years at war, but that is all.

\section{The results for the Rauch classification}

We shall next try to exploit the Rauch decomposition of bilateral trade between homogeneous goods, listed goods and differentiated goods in Table 5. Homogeneous goods are quoted on organized exchanges and consist entirely of primary products like corn, oil, wheat, etc. Listed goods are not quoted on organized exchanges yet are still standard enough to be bought on the basis of price lists without knowledge of the particular supplier. Examples are many standardized sorts or grades of fertilizers, chemicals, and (certain) wired rods or plates of iron and steel. ${ }^{12}$ In the case of differentiated goods, the purchaser buys from a specific supplier. Illustrations are automobiles, consumers' apparel, toys or cookware. Evidently we expect

\footnotetext{
${ }^{12}$ We use Rauch's conservative definition of the classifications.
} 
linguistic influences to become progressively more important as we go from homogeneous to listed to differentiated goods since the required information rises in this direction. For the same reason, we expect ethnic ties and trust to be more important as we move that way. The results for the three different categories support our hypotheses broadly; but there are some grey areas that we will not cover up.

The first column in Table 5 provides the same sort of panel estimates as in Table 3, while the next 5 columns offer the estimates for the odd years, as in Table 4. To economize on space, we present the coefficients strictly for the linguistic variables and, because of their related interest, for Common Religion. (More complete results appear in subsequent tables.) In the case of homogeneous goods, we omit CNL. If CNL serves as the sole linguistic variable (in estimates that we do not show), it is insignificant in half the individual years and has a low coefficient in the panel estimate over the period as a whole. Thus, it seems unimportant. However, when introduced jointly with CSL, the joint effect of CSL and CNL stays about the same but the coefficient of CSL rises and that of CNL turns negative in compensation, sometimes significantly so. It is difficult to make any sense of this last result. Furthermore, except for the change in the coefficient of CSL, CNL's absence has no effect on the rest of the estimate. This explains why we drop CNL. Following, the results suggest not only that language is strictly important in conveying information but also that the importance of language does not even require any public support through official status. COL is insignificant. The insignificance of Common Religion conforms broadly. It accords with the idea that the role of language owes nothing to personal affinities and trust. The only possible false note is the significance of LP, which only fits if LP can be properly regarded as reflecting strictly ease of translation. In that case, everything still hangs together and the results say that the importance of language for trade in homogeneous goods depends strictly on direct communication and ease of translation in a decentralized manner and without public support.

In the case of listed goods, CNL is not significant either but keeping it in the analysis raises no problem. CSL is not affected either way. COL, LP and common religion, as well as CSL, 
also retain the same coefficients regardless. They are all highly significant. The importance of COL in the presence of CSL and LP means that the support of translation through government auspices now matters. The relevance of religious ties is the only problematic aspect. If religious ties matter, why does CNL not matter as well? The importance of religious ties might also be regarded as a sign that the significance of LP partly reflects ethnic rapport and trust rather than strictly ease of communication through translation.

In the case of differentiated goods, the coefficient of COL is both significant and almost as large as that of CSL. Translation is highly important. For the first time, the significance of $\mathrm{CNL}$ is also difficult to deny even though CNL is not important every single year. However, we encountered various signs in our work that the significance of CSL and CNL are partly confused in the Rauch decomposition for differentiated goods, if not the rest. In estimates of mildly different samples, CNL sometimes appears more significant than in Table 5 in the panel results (though the significance of the variable is never consistently above conventional levels in all the years). We accept its significance.

The next Table, 6, tries to dig more deeply into the interpretation of LP in Table 5. Suppose that LP reflected strictly ethnic ties and trust. Then we would expect the high values of LP to be fundamental and the low values to make little difference. Our reasoning goes as follows. It is difficult to pin any ethnic interpretation on differences in LP when languages are distant; the differences would seem to be almost strictly lexical. By the same token, when it is question of ease of communication, then we would expect differences in LP to be just as important at the low as the high end. Take native German as an example. Since German is close to Dutch, we would expect the closer proximity of German to Dutch than to Italian to matter and this is so regardless whether LP owes its importance to ethnicity or ease of communication. However, if ethnic rapport was the only issue, then given the large distance between German and Hindi, we would not expect the difference between the proximity of German to Hindi and Japanese to matter even though Hindi is another Indo-European language and Japanese is not. On the other hand, if the issue is ease of communication, the greater proximity to Hindi than Japanese should matter just as much as the greater proximity 
to Dutch than Italian does.

Based on this line of reasoning, Table 6 divides LP2 between values greater than the median and values lower than the median. ${ }^{13}$ As can be seen, in the case of homogeneous goods, LP is equally important above and below the median and has about the same coefficient either way. However, for listed and heterogeneous goods, LP is solely important above the median. Those results fit nicely with the idea that LP in Table 5 reflects strictly the importance of costs of communication for homogeneous goods but reflects mostly instead the importance of ethnicity and trust for heterogeneous goods. However, the results reinforce our previous discomfort about the total insignificance of CNL for listed goods.

The results for Common legal system and Years at war in Table 6 are also interesting. Common legal system has a coefficient of 0.49 for homogeneous goods, a much lower coefficient of 0.22 which is still highly significant for listed goods, and a totally insignificant coefficient for heterogeneous goods. This would suggest some substitution between reliance on similar law and investment in information. Specifically, when little information is required, as for homogeneous goods, there is heavy reliance on similar law and when lots of information is required, there is enough investment in information to make similar law irrelevant. Note, finally, that the history of wars ceases to be uniformly significant and always bears the wrong sign when bilateral trade is divided by Rauch classification.

In closing this section, we may return to some fundamental conceptual issues. Based on the previous results as a whole, there is now strong reason to doubt the view that a COL implies that everyone receives messages in an official language for free (as in Melitz (2008)). Far more significantly, there is also reason to think that CSL reflects translation as well as direct communication. LP is the clue in both cases. On the first point, regarding COL, the results for homogeneous goods are central. LP matters for communicative ability whereas COL does not. This clearly does not agree with the idea that an official language means that all messages in the official language are available for free in one's own tongue (unless we also suppose that

\footnotetext{
${ }^{13}$ Notice that in this exercise LP2 is markedly more fitting than LP1.
} 
LP matters for all languages except official ones, which makes little sense). Consequently, even though we continue to consider the 0,1 character of COL to imply there are no variable costs of receiving messages from an official language, we now recognize some private fixed cost of receiving the messages or getting "hooked up" in this (or these two) language(s). Next, and more importantly, Tables 3 and 4, especially 4, clearly show that the introduction of LP reduces the coefficient of CSL. It does so not only for total trade but for all three Rauch categories separately (not shown). ${ }^{14}$ This would strongly suggest that CSL partly reflects bilingualism and translation and not only direct communication. The role of COL may be confined to translation, but CSL serves this role partly as well.

\section{A proposed aggregate index of a common language}

Is it possible to summarize the evidence about the linguistic influences in an index resting strictly on exogenous linguistic factors? That would be highly useful since we have many occasions to wish to control for such factors when our interest lies elsewhere. Moreover, on these occasions we sometimes work with small country samples when separate identification of several linguistic series may be extremely difficult. The answer to the question is yes. In other words, if we merely want to control for language in studying something else, a summary index of CL can rest on COL, CNL and LP alone. Let us first go back to the last column of Table 3 where we drop CSL. As seen, the sum of the influences of COL, CNL and LP in this column stays about the same as the sum of those of COL, CNL, LP plus CSL in the previous column. (It rises moderately.) Thus, whatever contribution spoken language makes to the explanation of bilateral trade in column 7 of Table 3 (an underestimate, in our view, because of simultaneity bias) is still present in column $8 .{ }^{15}$ Of course, it also follows that the coefficient of CNL in column 8 represents mostly the role of spoken rather than native language. We can perhaps attribute around 284/639 of the coefficient of CNL to native language as such.

\footnotetext{
${ }^{14}$ The negative impact of LP on the coefficient of CSL for listed and differentiated goods has separate interest in implying that LP refers partly to ease of communication rather than strictly ethnicity and trust for these goods.

${ }^{15}$ In principle, this is the outcome of two opposing forces. On the one hand, the elimination of the simultaneity bias increases the sum of the coefficients of the linguistic influences in column 8 relative to column 7 . On the other hand, the poorer reflection of linguistic influences in column 8 than column 7 produces an attenuation bias (a case of "errors in variables") and works the other way. Evidently the two effects approximately cancel out.
} 
Next, let us sum up the series for COL, CNL and LP and normalize the sum by dividing it by its highest value. This will yield an index of CL that is $0-1$. (Remember that LP2 had already been normalized to equal 1 , like COL, at the sample mean of its positive values.) ${ }^{16}$ Table 7 provides the resulting panel estimates for the same gravity equation as before for total bilateral trade and for the three separate Rauch classifications. Based on column 1, the coefficient of this CL index is only slightly higher than the sum of the coefficients of COL, CNL and LP in column 7 of Table 3. It is about 1.15 and very precisely estimated. The separate coefficients of CL for homogeneous, listed and differentiated goods show up in the next three successive columns. They go from 0.68 to 1.05 to 1.24 . All three are also precisely estimated, the coefficient for homogeneous goods less so than the other two. The rest of the equation is not affected by our aggregation of the linguistic influences in a single index. In particular, the earlier pattern of estimates of Common religion, Common legal system and Years at war occurs for the three Rauch classifications. Specifically, common religion is not significant for homogeneous goods but highly so for the other two classifications. Common legal system is highly significant for homogeneous goods, less so yet still highly significant for listed goods and no longer significant at all for heterogeneous goods. The coefficient of Years at wars is small, significant and with the right sign for the aggregate, but partly insignificant and always with the wrong sign for the Rauch decomposition.

In Appendix 2, Tables A2a-A2d, we offer the complete year by year estimates of the 4 panel estimates in Table 7. The annual estimates of the coefficients of CL are quite stable, as are the corresponding sums of the estimates of COL, CSL, CNL and LP2 in Table 4. It would seem then that abandoning CSL and reflecting it in the other three linguistic indices is acceptable as a means of controlling for exogenous linguistic factors. The annual values of CL move only from 1.04 to 1.23 for aggregate trade (Table A2a), from 0.95 to 1.13 for listed goods (A2c) and from 1.11 to 1.27 for differentiated goods (A2d). Only for homogeneous goods (A2b) is there a large movement, going from 0.51 to 0.89 . But a similar instability holds for these

\footnotetext{
${ }^{16}$ This not the only way to proceed but it is the simplest. A more sophisticated way would be to take into account the differences in the accuracy of the estimates of COL, CNL and LP. Yet the simplicity of our method is a recommendation (as otherwise the aggregate becomes a function of the estimates). It is especially so since the accuracies of the separate estimates of COL, CNL and LP are broadly comparable.
} 
goods in the earlier decomposition of the 4 linguistic influences. Note also, as regards homogeneous goods, that though COL is insignificant in the corresponding earlier estimate including CSL (Table 5), we cannot really drop COL from the CL index, for doing so worsens the performance of the index in Table A2b considerably (as we discovered). This clearly reflects the fact that in CSL's absence, COL captures a good deal of its influence (even if both CNL and LP are present). ${ }^{17}$

\section{The role of cross-migrants}

Thus far we have included no endogenous influences but CSL in the gravity equation. As mentioned earlier, however, one of the excluded influences notably alters the linguistic effects: namely, the stock of cross-migrants. Suppose we now add this variable. The particular measure of migration that we use, in conformity with our focus on aggregate demand behavior and imports is the (log of) the stock of emigrants in the importing country from the exporting one. Thus, for French imports from Germany, for example, this stock is the stock of German emigrants in France. Note also that our measure reflects the stock of emigrants in the year 2000 . Further, by using it we lose about $10 \%$ of the observations.

In line with much earlier work on the subject of the role of emigrants in trade between host and home country, this stock of emigrants proves extremely important (Gould (1994), Head and Ries (1998), Dunlevy and Hutchinson (1999), Wagner et al. (2002), and Rauch and Trindade (2002)). ${ }^{18}$ As we see from Table 8a, once we introduce Migration (log) in our aggregate trade equation its coefficient enters with a very precisely estimated coefficient of 0.18 and the coefficients of COL, CSL and LP drop while that of CNL becomes uniformly

\footnotetext{
${ }^{17}$ Santos Silva and Tenreyro (2006) recommend the use of Poisson pseudo-maximum-likelihood (PPML) in order to avoid the problems resulting if the residuals happen to be linear. In light of the influence of their work, we have experimented with PPML even though we assume log-linear residuals in line with our general loglinear specification of the gravity model. Our results do not agree with theirs. Whereas they obtain sensible results with PPML, our own reinforce our choice of sticking to the assumption of log-linear residuals in accordance with the rest of our specification. In our PPML experiments, the influence of distance survives and swallows up the importance of most of the rest of the gravity variables, including not only language, but the colonial controls and common religion. There are good reasons for this, since bilateral trade and distance are the only two variables in our specification that vary widely in levels. The rest of our variables remain unchanged.

${ }^{18}$ Of some note as well, the most recent literature on the relation between language and migration includes some attempts to use several measures of linguistic influence at once. See Belot and Eberveen (2010) and Adsera and Pytlikova (2011).
} 
insignificant. Those changes from the earlier estimates in Table 4 are also very stable year by year. In addition, corresponding changes take place in the three Rauch classifications following the decomposition (compare Table $8 \mathrm{~b}$ with the earlier estimates in Table 5). Note in particular the pretty clear lack of significance of CNL for differentiated goods.

According to Table $8 \mathrm{a}$, there are three separate significant linguistic influences on bilateral trade, COL, CSL and LP. If we add up the coefficients of the three we obtain 0.69. However, the coefficient of CSL in this total is an underestimate. If we try to correct for this flaw by using our proposed aggregate index of linguistic influences (which then removes the endogenous response of CSL though at the cost of a poorer reflection of CSL), we get a coefficient of 0.87 (not shown). One might then argue that the right estimate of the impact of linguistic factors on trade is around $0.69-0.87$. But we would question this interpretation. In the first place, the stock of emigrants from any country in any other clearly depends partly on language, both directly because of a tendency to emigrate where the language is the same ${ }^{19}$ and, indirectly, via the impact of bilateral trade on bilateral migration. Even independently, the stock of emigrants from the home country can itself be seen partly as a linguistic variable or a linguistic influence on imports. It has been treated as such in the past, if only implicitly, since the variable has never appeared in gravity equations side by side with an index of a common language except when the stock of emigrants itself was a center of interest. Only detailed study will tell us in the future what part of the changes in the estimates in Tables 8a and $8 \mathrm{~b}$ associated with emigrants can be considered as totally independent of language. For the time, we consider that around 25 to $38 \%$ of our estimate of 1.15 of the impact of CL in Table 7 has some linguistic association with emigrants. We also consider that this part of the estimate embraces most everything in the impact of common language on bilateral trade that has to do with ethnicity and trust.

\section{English as a separate language}

The analysis thus far supposes that the particular language makes no difference. Many would

\footnotetext{
${ }^{19}$ One particularly arresting study is Falk et al. (2010), which provides evidence of the impact of different regional German dialects on regional migration within Germany based on a singular late-nineteenth-century dataset. See also both references in the preceding note.
} 
question this assumption, for English in particular. We therefore tested the separate importance of English, and the other major world languages too, and we summarize the results in Table 9, where we concentrate on English. The first test, column 1, is purely expository. It treats English as the only common language. Suppose that all of our results depended on English alone (a view that we encountered). Then the measures of COL, CSL, CNL and LP2 in this first column would remove errors of measurement and yield higher and better estimated coefficients. Suppose instead that our measures of CL are the correct ones. Then the measures of CL in this column would be noisy and yield lower and less well estimated coefficients than the previous ones. But in this last case - that is, if our measures of $\mathrm{CL}$ are the appropriate ones - it is important to observe that there are two reasons why the English-based measures of CL might perform particularly badly.

In the first place, an English-speaking country has a great many solutions for skirting the language barrier altogether. There are lots of other English-speaking countries with which it could trade. Therefore, common English can be expected to be an especially weak spur to trade with any single common-language partner. Alternatively, a country speaking Portuguese, for example, would have far fewer alternative partners with which to trade in order to avoid the language barrier and therefore might exploit those opportunities more intensely. ${ }^{20}$ This is the identical point that Anderson and van Wincoop (2003) made in explaining why national trade barriers formed a far more powerful incentive for bilateral trade between two Canadian provinces than between two US states. On this ground, the coefficients of the CL variables based on English alone might be exceptionally low apart from measurement error. The second point could be even more serious. Relying on English alone means drawing numerous distinctions between country pairs who share a different common language than English based upon their English, and proposing a quantitative ordering of linguistic ties between these non-English pairs based on their common English alone. Especially large distortions might arise.

\footnotetext{
${ }^{20}$ Of course, for that very reason, people in the Portuguese-speaking country would have stronger incentives to become multilingual. But while this diminishes the weight of the point, it does not deny it altogether. Note also that the higher multilateral trade barrier facing the Portuguese-speaking country because of language is independently captured by our country fixed effects.
} 
The results in column 1 basically confirm our broad suspicion that a measure of CL resting on English alone would perform badly. COL, CSL and CNL for English are insignificant. The same tests for the 3 next largest languages in our database - French, Spanish and Arabic are no worse, though not particularly better. It is true, however, that LP2 matters for English, a point to which we will return.

Column 2 is the genuine test. It examines whether adding separate measures of CL for English to the earlier measures in the tests supports a separate consideration of English. In this case, the results are entirely negative for COL, CSL and CNL. For all three measures, the sign of CL without any separate notice of English and the one based on English alone go in opposite directions (the signs of COL and CSL becoming significantly negative for English). There is no sense in this. Given the high quality of the results for CL in the absence of special attention to English, the only inference is that the separate consideration of the language is unfounded. These last results are reminiscent of those we obtained when we introduced CNL together with CSL for homogeneous goods. In this case too the signs of CNL and CSL went in opposite directions (the sign of CNL becoming significantly negative) and we drew the same (or the corresponding) inference that CNL should not be introduced jointly with CSL. However, as regards LP2, English is still separately significant in column 2.

The similar tests for French, Spanish and Arabic yield similar results. In order to provide some summary indication, column 3 presents the results of the test for a combined measure of CL lumping together the major European world languages besides English - French, Spanish, German and Portuguese. Quite specifically, the measures of CL for these 4 languages in column 3 follow from our method of construction after setting all the values for languages in our database except these 4 equal to zero. As can be seen, broadly speaking, this alternative set of languages as a group yields no better results than English does (though in the case of COL the combined measure does do better than English, as is true for French and Spanish separately). We also find, rather uncomfortably, that linguistic proximity harms bilateral trade for this combination of languages, which is possibly simply a reflection of the earlier result that native English helps exceptionally since English figures prominently in the other measure 
of LP2 in column 3 (whose effect is now correspondingly higher). In other separate estimates for individual languages, we also find that LP2 helps to interpret foreign languages for Spanish and is harmful for French and Arabic. All these results about the significance of separate native languages in interpreting foreign languages based on linguistic proximity remain a mystery to us.

With this last caveat, we conclude that the distinction of English, or any other major language for that matter, is not warranted. Once we control for distance, contiguity, ex-colonialism, law, religion, the history of wars, and country/year fixed effects or "multilateral trade resistance" in Anderson and Van Wincoop's (2003) terms, all that really matters is common language, whatever the language may be.

\section{Discussion and conclusion}

It is common practice in the trade literature to use a binary 0,1 variable to control for a CL. We have shown that this practice takes us way off the mark in estimating the impact of linguistic factors on bilateral trade. Probably the most clear-cut basis for answering yes or no to the presence of a CL is a COL. Country samples of any size where, even as a rough approximation, every individual in all pairs has the same native language or else no one in all pairs shares a native language with anyone in the opposite country are either imaginary or highly unlikely. Yet it is precisely when official status serves as the basis for a dummy variable for a $C L$ that the underestimate of $C L$ is greatest, in the order of one-half.

In sum, there is no way to embrace the influence of language on bilateral trade by using a measure of CL along any single dimension. Only a measure embracing a broad range of the linguistic influences on bilateral trade will do. One source of linguistic influence that sometimes gets primary attention is ethnic ties. This is particularly true in studies that center on emigrants (e.g., Rauch and Trindade (2002)). Admittedly, the linguistic influences on trade stemming from immigrants probably owe much to ethnicity and trust. However, ease of communication is far and away more important as a general factor. According to our results, the role of ease of communication in trade also hinges largely on translation and interpreters. 
Translation and interpreters enter partly via official status and partly through bilingualism in general together with linguistic proximity. Since few people possess more than two or three languages, yet there are nearly 400 languages spoken by over a million people (Ethnologue) in a world consisting of 200-some countries, it makes sense that translation and interpreters would matter in easing communication in trade. ${ }^{21}$

It might seem curious at first that ease of communication would have as large an effect as we find in the case of homogeneous goods, since all the required information for bilateral trade seems minimal. In our estimate, an additional percentage point of CL increases bilateral trade in these goods by 0.68 of a percentage point or quite a lot. Upon reflection, however, we can see the possible reason. The ability to communicate in depth is never irrelevant in trade since things can go wrong. Goods may arrive late or damaged; contracts may not be honored; there may need to be recourse to the small print. Perhaps it is relevant too in this connection that a common legal system matters as well for homogeneous goods. It enters with a semi-elasticity of 0.44 , not that far below 0.68 , though ethnicity and common religion are both irrelevant.

Once detailed information becomes pertinent in trade, as it is for differentiated goods, we may expect the impact of language to go up. Based on our summary index of CL, the semielasticity of influence of a CL indeed rises from 0.68 for homogeneous goods to 1.24 for differentiated goods. In addition, the heightened effect of language in the case of differentiated goods might be expected to act as a special spur to language learning. This too appears confirmed in our results. There is clear evidence of simultaneity bias in Table 3 for goods in general. When CSL and CNL enter together, CSL strongly dominates CNL, but when either of them stands alone for all linguistic factors CSL (which trade can affect even within a year) has a lower coefficient than CNL (which trade can only affect over generations via demography). This would indicate a positive reciprocal effect of trade on language which, though of the same sign as the one of language on trade, is weaker and therefore dilutes the

\footnotetext{
${ }^{21}$ Of considerable note, though, interpreters and translation are probably far less effective in production within a firm than in trade. Labor studies show a substantial positive return to the command of the principal home language on the wages of immigrants. See McManus, Gould and Welch (1983), Chiswick and Miller (1995, 2002, 2007), Dustmann and van Soest (2002), and Dustmann and Fabbri (2003). We would conjecture that the wage return would be lower if translation and interpreters were as effective in production as they are in trade.
} 
latter. However, if we repeat this test by separate Rauch category (not shown), we find that the result hinges basically on differentiated goods. There is no similar sign of a reciprocal effect of trade on language for homogenous and listed goods viewed either separately or together.

It is also interesting to relate our results to the burgeoning empirical evidence about individual firm activity in foreign trade. We know that there is a high incidence of exporting firms that limit their foreign activity to a few countries. We also know that the percentage of firms that export to as many as 5 foreign destinations is rather small and that these firms are unusually big and efficient (see Bernard et al. (2008), Eaton et al. (2011), and Mayer and Ottaviano (2007)). Evidently, if the large impact of language on trade in our results stems notably from a fixed cost of crossing a language barrier at the level of the individual firm, our results would contribute to understanding these facts. Indeed, Mayer and Ottaviano (2007) already suggest that this may be true. They show, for France, not only that the percentage of individual firms who export to other French-speaking destinations is unusually large but also that the firms who exploit this linguistic advantage have lower average productivity than the rest of French exporting firms. This fits nicely, since the lower fixed costs of these firms than the rest would mean that they require lower efficiency than the others in order to export profitably. If we follow this line of reasoning, there is a new extensive margin to consider at the level of the firm: the number of language destinations. One prediction, for example, would be that among firms who export to 10 destinations, those who do so to countries who all practice the same language would be less efficient than the rest (they have lower fixed costs to overcome). At the other end of the spectrum, in the Eaton et al. (2011) dataset for France, the firms who export to 75 or more destinations (who numbered only 244 in 2004) constitute a tiny fraction of 1 percent of French exporters and, on a rough estimate, cross 31 language frontiers on average (around 7 for languages that are not common ones in our study). ${ }^{22}$ Based on our previous conjecture, the significance of translation and interpreters would help understand these firms' ability to traverse so many linguistic frontiers. The fixed

\footnotetext{
${ }^{22}$ We had access to the same database as these authors for more recent years and made the estimate ourselves.
} 
cost of the language frontier that these firms encounter probably has little tendency to decline on the extensive margin. Therefore, if those fixed costs depended on direct communication, it is a reasonable guess that the firms would export to fewer foreign language destinations despite their exceptional productivity. These are all subjects for further investigation.

Another extension of this study that might be especially worthwhile would be to examine the benefits of promoting language-learning through public policy, English in particular. Some warning signs should be posted in this regard. We found no special significance of English in explaining bilateral trade. Nonetheless, from a world perspective, it is pretty clear that English-learning will do the world more good than learning any other language. That is, once we sum up over all countries, if we can abstract from differences in the costs of learning different languages, any amount of resources devoted to learning English will reduce the Dixit-Stiglitz utility-based price level or $\mathrm{P}_{\mathrm{i}}$ in eq. (1) more than learning any other language and thereby will boost world consumption more. Yet even as concerns $\mathrm{P}_{\mathrm{i}}$, matters will vary by country. For example, in Kazakhstan or Kyrgyzstan, good Russian probably remains more important than good English. Over and above, the importance of English in trade may be widely reflected in existing public policies to teach English and private incentives to learn the language. Do public policies to teach English in school curriculums and private incentives to learn it fall short from a social perspective? The answer is not obvious, partly because of the role of translation, but also because of the possibility of greater social neglect of returns from learning other languages, which are also in demand but scarcer on the market ${ }^{23}$ and which may be greater sources of utility in particular regional or national environments. The underlying problem is that language learning has major external effects that individuals neglect in their learning decisions (see, for example, Church and King (1993)). In addition, public choices about schooling may not properly repair the resulting shortfalls in social utility. There is also the larger question of the optimum number of languages in the world, which we are prone to regard as requiring a broader framework where separate languages do

\footnotetext{
${ }^{23}$ See, in particular, Ginsburg and Prieto (2010) who show that some languages other than English yield higher personal returns than English as second languages in various member countries of the EU outside of Ireland and the UK.
} 
not appear strictly as impediments to trade. The right framework, we think, would recognize people's attachment to their maternal language and the benefits of linguistic diversity as a source of pleasure and variety in consumption. 


\section{$\underline{\text { References }}$}

Adsera, Alicia and Mariola Pytlikova, 2011. The role of language in shaping international migration: Evidence from OECD countries 1985-2006. Mimeo.

Alesina, Alberto, Arnaud Devleeschauwer, William Easterly, Sergio Kurlat and Romain Wacziarg, 2003. Fractionalization. Journal of Economic Growth 8, 155-194.

Anderson, John and Erich van Wincoop, 2003. Gravity with gravitas: A solution to the border problem. American Economic Review 93, 170-192.

Anderson, John and Erich van Wincoop, 2004. Trade costs. Journal of Economic Literature $42,691-751$.

Armington, Paul, 1969. A Theory of Demand for Products Distinguished by Place of Production. International Monetary Fund Staff Papers 16, 159-176.

Baier, Scott and Bergstrand, Jeffrey, 2007. Do free trade agreements actually increase members' international trade? Journal of International Economics 71, 72-95.

Bakker, Dik, André Müller, Viveka Velupillai, Søren Wichmann, Cecil Brown, Pamela Brown, Dimitry Egorov, Robert Mailhammer, Anthony Grant and Eric Hollman, 2009. Linguistic Typology 13, 167-179.

Belot, Michele and Sjef Ederveen (2010). Cultural and institutional barriers in migration between OECD countries. Forthcoming in Journal of Population Economics.

Bernard, Andrew, J. Bradford Jensen, Stephen Redding and Peter Schott 2007. Firms in international trade. Journal of Economic Perspectives 21, 105-130.

Boisso, Dale and Michael Ferrantino, 1997. Economic distance, cultural distance, and openness in international trade: Empirical puzzles. Journal of Economic Integration 12, 456-484.

Brown, Cecil, Eric Holman, Søren Wichmann and Viveka Velupillai, 2008. Automatic classification of the world's languages: A description of the method and preliminary results. Language Typology and Universals 61(4), 285-308.

Central Intelligence Agency, World Factbook, US Government Printing Office, available online.

Chiswick, Barry and Paul Miller, 1995. The endogeneity between language and earnings: International analyses. Journal of Labor Economics 13, 246-248.

Chiswick, Barry and Paul Miller, 1998. English language fluency among immigrants in the United States. Research in Labor Economics 17, 151-200.

Chiswick, Barry and Paul Miller, 2002. Immigrant earnings: Language skills, linguistic concentration and the business cycle. Journal of Population Economics 15 (1), 312-57.

Chiswick, Barry and Paul Miller, 2004. Linguistic distance: A quantitative measure of the distance between English and other languages. IZA Discussion Paper 1246, August. 
Chiswick, Barry and Paul Miller, 2007. Computer usage, destination language proficiency and the earnings of natives and immigrants. Review of the Economics of the Household $5(2), 129-157$.

Church, Jeffrey and Ian King, 1993. Bilingualism and network externalities. Canadian Journal of Economics, 337-345.

Crystal, David, 1997. English as a Global Language. Cambridge University Press, Cambridge.

Crystal, David, 2003. The Cambridge History of the English Language. Cambridge University Press, Cambridge, $2 \mathrm{~d}$ edition.

Desmet, Klaus, Ignacio Ortuño-Ortin and Shlomo Weber, 2009 (a). Linguistic diversity and redistribution. Journal of the European Economic Association 7 (6), 1291-1318.

Desmet, Klaus, Ignacio Ortuño-Ortin and Romain Wacziarg, 2009 (b). The political economy of ethnolinguistic cleavages. CEPR Discussion Paper no. 7478.

Dunlevy, James and William Hutchinson, 1999. The impact of immigration on American import trade in the late nineteenth and early twentieth centuries. Journal of Economic History 59, 1043-1062.

Dustmann, Christian and Francesca Fabbri, 2003. Language proficiency and labour market performance of immigrants in the UK. Economic Journal, 113(489), 695-717

Dustmann, Christian and Arthur van Soest, 2002. Language and the earnings of immigrants. Industrial and Labor Relations Review 55 (3), 473-492.

Dyen, Isidore, Joseph Kruskal and Paul Black, 1992. An Indo-European classification: An Indo-European classification: A lexicostatistical experiment. Transactions of the American Philosophical Society 82 (5).

Eaton, Jonathan and Samuel Kortum, 2002. Technology, geography and trade. Econometrica $70,1741-1779$.

Eaton, Jonathan, Samuel Kortum and Francis Kramarz, 2011. An anatomy of international trade: evidence from French firms. Econometrica 79, 1453-1498.

Egger, Peter, Mario Larch, Kevin Staub and Rainer Winkelmann, 2011. The trade effects of endogenous preferential trade agreements. American Journal of Economic Policy 3, 113-143.

Egger, Peter and Andrea Lassmann, 2011. "The language effect in international trade: A meta-analysis," CESifo Working Paper no. 3682 (December).

Ethnologue: Languages of the World, 2009. 16th ed. Summer Institute of Linguistics, International Academic Bookstore, Dallas, TX, available online.

Falck, Oliver, Stefan Heblich, Alfred Lameti and Jens Südekum, 2010. Dialects, cultural identity, and economic exchange. IZA Discussion Paper No. 4743, February. 
Fearon, James (2003). Ethnic and cultural diversty by country. Journal of Economic Growth $8,195-222$.

Felbermayr, Gabriel and Farid Toubal, 2010. Cultural proximity and trade. European Economic Review 54, 279-293.

Foroutan, Faezeh and Lant Pritchett, 1993. Intra-Sub-Saharan African trade: Is it too little? Journal of African Economics 2, 74-105.

Frankel, Jeffrey, 1997. Regional trading blocs in the world trading system. Institute for International Economics.

Frankel, Jeffrey and Andrew Rose, 2002. An estimate of the effect of common currencies on trade and income. Quarterly Journal of Economics 117, 437-466.

Frankel, Jeffrey, Ernesto Stein and Shang-Jin Wei, 1998. Continental trading blocs: Are they natural or supernatural? In: Frankel, Jeffrey (Ed.), The Regionalization of the World Economy. The University of Chicago Press, pp. 91-113.

Gaulier, Guillaume and Soledad Zignago, 2010. BACI: International trade database at the product-level: The 1994-2007 version. CEPII Working Paper, 2010-23.

Ginsburgh, Victor and Shlomo Weber, 2011. How many languages do we need? The economics of linguistic diversity. Princeton University Press.

Ginsburgh, Victor and Juan Prieto-Rodriguez, 2007. Returns to foreign languages of native workers in the EU. Industrial \& Labor Relations Review 64, 599-618.

Giuliano, Paola, Antonio Spilimbergo and Giovanni Tonon, 2006. Genetic, cultural and geographical distances. CEPR discussion paper 5807.

Gould, David, 1994. Immigrant links to the home country: Empirical implications for US bilateral trade flows. Review of Economics and Statistics 69, 301-316.

Guiso, Luigi, Paola Sapienza and Luigi Zingales, 2009. Cultural biases in economic exchange, Quarterly Journal of Economics 124, 1095-1131.

Havrylyshyn, Oleh and Lant Pritchett, 1991. European trade patterns after the transition. Policy, Research, and External Affairs Working Paper, World Bank.

Head, Keith and John Ries,1998. Immigration and trade creation: Econometric evidence from Canada. Canadian Journal of Economics 31, 46-62.

Head, Keith, Thierry Mayer and John Ries, 2010. The erosion of colonial trade linkages after independence. Journal of International Economics 81(1), 1-14.

Helble, Matthias (2007). Is God good for trade. Kyklos 60(3), 385-413.

Helpman, Elhanan, Marc Melitz and Yona Rubinstein, 2008. Estimating trade flows: Trading partners and trading volumes. Quarterly Journal of Economics 123, 441-488.

Holman, Eric, Christian Schultze, Dietrich Stauffer and Søren Wichmann, 2007. On the relation between structural diversity and geographical distance among languages: 
Observations and computer simulations. Linguistic Typology 11(2), 393-422.

Hummels, David, 2001. Towards a geography of trade costs. Working Paper, Purdue University.

Hutchinson, William, 2005. 'Linguistic distance' as a determinant of bilateral trade. Southern Economic Journal 72(1), 1-15.

International Religious Freedom, 2007. http://www.state.gov/g/drl/rls/irf/2007/index.htm

$\mathrm{Ku}$, Hyejin and Asaf Zussman, 2010. Lingua franca: The role of English in international trade. Journal of Economic Behavior \& Organization 75, 250-260.

Laitin, David, 2000. What is a language community? American Journal of Political Science 44, 142-155.

Lewer, Joshua and Hendrik van den Berg 2007. Estimating the institutional and network effects of religious cultures on bilateral trade. Kyklos 60 (2), 255-277.

Martin, Philippe, Thierry Mayer and Mathias Thoenig, 2008. Make Trade not War? Review of Economic Studies 75(3), 865-900.

Mayer, Thierry and Gianmarco Ottaviano, 2007. The Happy Few: The Internationalisation of European Firms: New Facts Based on Firm-level Evidence. Bruegel Blueprint Series vol. III.

McManus, Walter, William Gould and Finis Welch, 1983. Earnings of Hispanic men: The role of English language proficiency. Journal of Labor Economics 1, 101-130.

Melitz, Jacques, 2008. Language and foreign trade. European Economic Review 52, 667-699.

Parsons, Christopher, Ronald Skeldon, Terrie Walmsley and Alan Winters 2007. Quantifying International Migration : A Database of Bilateral Migrant Stocks. World Bank Policy Research Working Paper No. 4165.

Persson, Torsten, 2001. Currency Union and Trade: How Large is the Treatment Effect? Economic Policy 33, 433-448.

Pew Research Center's Forum on Religion \& Public Life, 2009. Mapping the Global Muslim Population: A Report on the Size and Distribution of the World's Muslim Population. October, 2009, The Pew Research Center.

Rauch, James, 1999. Networks versus markets in international trade. Journal of International Economics 48, 7-35.

Rauch, James and Vitor Trindade, 2002. Ethnic Chinese networks in international trade. Review of Economics and Statistics 84, 116-130.

Rose, Andrew, 2000. One money, one market: the effect of common currencies on trade. Economic Policy 30, 7-45.

Rose, Andrew, 2001. Currency unions and trade: the effect is large, Economic Policy 33, 449461. 
Santos Silva, J. M. C. and Silvana Tenreyro, 2006. The log of gravity. The Review of Economics and Statistics 88 (4), 641-658.

Sarkees, Meredith Reid and Frank Wayman, 2010. Resort to War: 1816 - 2007. CQ Press.

Special Eurobarometer 243, 2006. Europeans and their languages. The European Commission.

Swadesh, Morris, 1952. Lexico-statistic dating of prehistoric ethnic contacts. Proceedings of the American Philosophical Society 96, 121-137.

Wagner, Don, Keith Head and John Ries, 2002. Immigration and the trade of provinces. Scottish Journal of Political Economy. 49, 507-525.

World Christian Database, 2005. www.worldchristiandatabase.org. 
Table 3: Common language

Regressand: log of bilateral trade (Total)

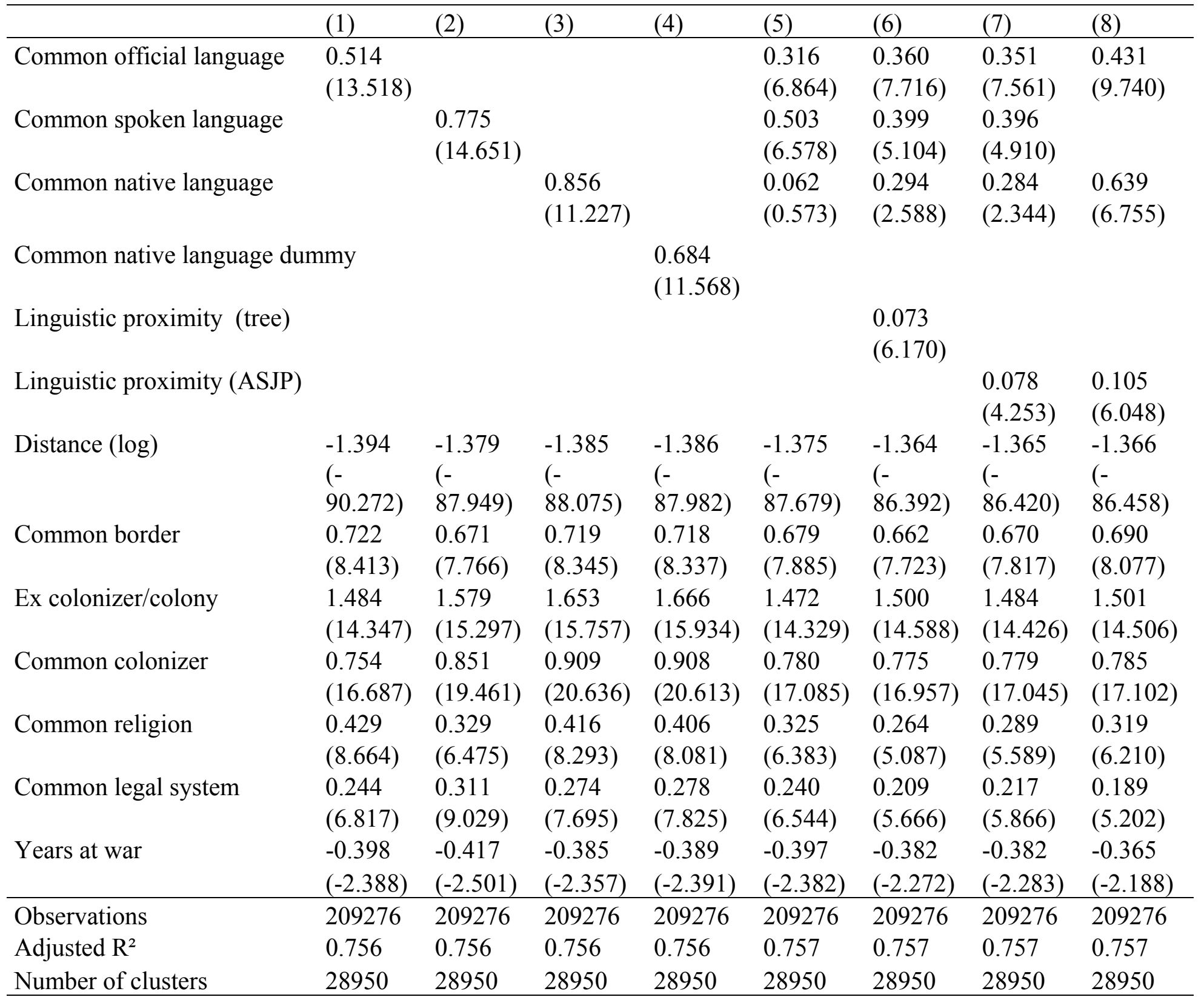

All regressions contain exporter/year and importer/year fixed effects. Student $t s$ are in parentheses. These are based on robust standard errors that have been adjusted for clustering by country pair. 
Table 4: Common language (yearly estimates)

Regressand: log of bilateral trade (Total)

\begin{tabular}{|c|c|c|c|c|c|c|c|c|c|c|}
\hline & 1999 & 1999 & 2001 & 2001 & 2003 & 2003 & 2005 & 2005 & 2007 & 2007 \\
\hline Common official language & $\begin{array}{l}0.224 \\
(3.384)\end{array}$ & $\begin{array}{l}0.260 \\
(3.890)\end{array}$ & $\begin{array}{l}0.279 \\
(4.474)\end{array}$ & $\begin{array}{l}0.313 \\
(4.971)\end{array}$ & $\begin{array}{l}0.392 \\
(6.544)\end{array}$ & $\begin{array}{l}0.418 \\
(6.918)\end{array}$ & $\begin{array}{l}0.357 \\
(5.926)\end{array}$ & $\begin{array}{l}0.395 \\
(6.505)\end{array}$ & $\begin{array}{l}0.252 \\
(4.134)\end{array}$ & $\begin{array}{l}0.286 \\
(4.647)\end{array}$ \\
\hline Common spoken language & $\begin{array}{l}0.506 \\
(4.660)\end{array}$ & $\begin{array}{l}0.393 \\
(3.480)\end{array}$ & $\begin{array}{l}0.496 \\
(4.781)\end{array}$ & $\begin{array}{l}0.393 \\
(3.637)\end{array}$ & $\begin{array}{l}0.446 \\
(4.414)\end{array}$ & $\begin{array}{l}0.368 \\
(3.478)\end{array}$ & $\begin{array}{l}0.467 \\
(4.695)\end{array}$ & $\begin{array}{l}0.348 \\
(3.343)\end{array}$ & $\begin{array}{l}0.627 \\
(6.223)\end{array}$ & $\begin{array}{l}0.528 \\
(5.000)\end{array}$ \\
\hline Common native language & $\begin{array}{l}0.179 \\
(1.203)\end{array}$ & $\begin{array}{l}0.418 \\
(2.530)\end{array}$ & $\begin{array}{l}0.086 \\
(0.609)\end{array}$ & $\begin{array}{l}0.298 \\
(1.888)\end{array}$ & $\begin{array}{l}-0.040 \\
(-0.286)\end{array}$ & $\begin{array}{l}0.121 \\
(0.778)\end{array}$ & $\begin{array}{l}0.126 \\
(0.926)\end{array}$ & $\begin{array}{l}0.369 \\
(2.429)\end{array}$ & $\begin{array}{l}0.102 \\
(0.754)\end{array}$ & $\begin{array}{l}0.302 \\
(2.000)\end{array}$ \\
\hline Linguistic proximity (ASJP) & & $\begin{array}{l}0.082 \\
(3.410)\end{array}$ & & $\begin{array}{l}0.075 \\
(3.134)\end{array}$ & & $\begin{array}{l}0.056 \\
(2.395)\end{array}$ & & $\begin{array}{l}0.085 \\
(3.678)\end{array}$ & & $\begin{array}{l}0.071 \\
(3.053)\end{array}$ \\
\hline Distance (log) & $\begin{array}{l}-1.340 \\
(-61.854)\end{array}$ & $\begin{array}{l}-1.330 \\
(-61.031)\end{array}$ & $\begin{array}{l}-1.347 \\
(-65.369)\end{array}$ & $\begin{array}{l}-1.338 \\
(-64.511)\end{array}$ & $\begin{array}{l}-1.402 \\
(-69.489)\end{array}$ & $\begin{array}{l}-1.394 \\
(-68.688)\end{array}$ & $\begin{array}{l}-1.409 \\
(-69.804)\end{array}$ & $\begin{array}{l}-1.397 \\
(-68.786)\end{array}$ & $\begin{array}{l}-1.383 \\
(-66.653)\end{array}$ & $\begin{array}{l}-1.373 \\
(-66.026)\end{array}$ \\
\hline Common language & $\begin{array}{l}0.699 \\
(6.945)\end{array}$ & $\begin{array}{l}0.689 \\
(6.868)\end{array}$ & $\begin{array}{l}0.682 \\
(7.247)\end{array}$ & $\begin{array}{l}0.672 \\
(7.169)\end{array}$ & $\begin{array}{l}0.721 \\
(7.084)\end{array}$ & $\begin{array}{l}0.715 \\
(7.041)\end{array}$ & $\begin{array}{l}0.739 \\
(7.390)\end{array}$ & $\begin{array}{l}0.731 \\
(7.326)\end{array}$ & $\begin{array}{l}0.638 \\
(5.892)\end{array}$ & $\begin{array}{l}0.629 \\
(5.833)\end{array}$ \\
\hline Ex colonizer/colony & $\begin{array}{l}1.595 \\
(14.141)\end{array}$ & $\begin{array}{l}1.606 \\
(14.221)\end{array}$ & $\begin{array}{l}1.438 \\
(12.591)\end{array}$ & $\begin{array}{l}1.450 \\
(12.674)\end{array}$ & $\begin{array}{l}1.464 \\
(12.895)\end{array}$ & $\begin{array}{l}1.473 \\
(12.957)\end{array}$ & $\begin{array}{l}1.416 \\
(12.258)\end{array}$ & $\begin{array}{l}1.429 \\
(12.353)\end{array}$ & $\begin{array}{l}1.325 \\
(11.596)\end{array}$ & $\begin{array}{l}1.335 \\
(11.675)\end{array}$ \\
\hline Common colonizer & $\begin{array}{l}0.826 \\
(11.883)\end{array}$ & $\begin{array}{l}0.823 \\
(11.840)\end{array}$ & $\begin{array}{l}0.743 \\
(11.853)\end{array}$ & $\begin{array}{l}0.742 \\
(11.837)\end{array}$ & $\begin{array}{l}0.753 \\
(12.789)\end{array}$ & $\begin{array}{l}0.752 \\
(12.769)\end{array}$ & $\begin{array}{l}0.774 \\
(13.402)\end{array}$ & $\begin{array}{l}0.773 \\
(13.379)\end{array}$ & $\begin{array}{l}0.776 \\
(13.364)\end{array}$ & $\begin{array}{l}0.776 \\
(13.347)\end{array}$ \\
\hline Common religion & $\begin{array}{l}0.353 \\
(4.773)\end{array}$ & $\begin{array}{l}0.312 \\
(4.166)\end{array}$ & $\begin{array}{l}0.272 \\
(3.847)\end{array}$ & $\begin{array}{l}0.237 \\
(3.298)\end{array}$ & $\begin{array}{l}0.363 \\
(5.311)\end{array}$ & $\begin{array}{l}0.337 \\
(4.868)\end{array}$ & $\begin{array}{l}0.340 \\
(4.995)\end{array}$ & $\begin{array}{l}0.302 \\
(4.395)\end{array}$ & $\begin{array}{l}0.384 \\
(5.575)\end{array}$ & $\begin{array}{l}0.352 \\
(5.040)\end{array}$ \\
\hline Common legal system & $\begin{array}{l}0.214 \\
(4.167)\end{array}$ & $\begin{array}{l}0.191 \\
(3.670)\end{array}$ & $\begin{array}{l}0.234 \\
(4.676)\end{array}$ & $\begin{array}{l}0.212 \\
(4.194)\end{array}$ & $\begin{array}{l}0.235 \\
(4.844)\end{array}$ & $\begin{array}{l}0.218 \\
(4.443)\end{array}$ & $\begin{array}{l}0.226 \\
(4.694)\end{array}$ & $\begin{array}{l}0.201 \\
(4.137)\end{array}$ & $\begin{array}{l}0.308 \\
(6.378)\end{array}$ & $\begin{array}{l}0.287 \\
(5.883)\end{array}$ \\
\hline Years at war & $\begin{array}{l}-0.477 \\
(-2.784)\end{array}$ & $\begin{array}{l}-0.461 \\
(-2.677)\end{array}$ & $\begin{array}{l}-0.383 \\
(-2.296)\end{array}$ & $\begin{array}{l}-0.370 \\
(-2.208)\end{array}$ & $\begin{array}{l}-0.294 \\
(-1.559)\end{array}$ & $\begin{array}{l}-0.283 \\
(-1.499)\end{array}$ & $\begin{array}{l}-0.359 \\
(-1.951)\end{array}$ & $\begin{array}{l}-0.344 \\
(-1.858)\end{array}$ & $\begin{array}{l}-0.404 \\
(-2.151)\end{array}$ & $\begin{array}{l}-0.391 \\
(-2.072)\end{array}$ \\
\hline Observations & 18712 & 18712 & 20605 & 20605 & 21760 & 21760 & 22387 & 22387 & 22621 & 22621 \\
\hline Adjusted $\mathrm{R}^{2}$ & 0.751 & 0.751 & 0.749 & 0.749 & 0.755 & 0.755 & 0.758 & 0.758 & 0.763 & 0.763 \\
\hline
\end{tabular}

All regressions contain exporter and importer fixed effects. Student ts are in parentheses. These are based on robust standard errors. 
Table 5: Common language (Panel and Yearly estimates)

Regressand: log of bilateral trade (Rauch categories)

\begin{tabular}{|c|c|c|c|c|c|c|}
\hline & Panel & 1999 & 2001 & 2003 & 2005 & 2007 \\
\hline \multicolumn{7}{|l|}{ Homogeneous } \\
\hline Common official language & $\begin{array}{l}0.027 \\
(0.404)\end{array}$ & $\begin{array}{l}0.047 \\
(0.487)\end{array}$ & $\begin{array}{l}-0.074 \\
(-0.790)\end{array}$ & $\begin{array}{l}0.141 \\
(1.546)\end{array}$ & $\begin{array}{l}0.043 \\
(0.474)\end{array}$ & $\begin{array}{l}-0.001 \\
(-0.009)\end{array}$ \\
\hline Common spoken language & $\begin{array}{l}0.676 \\
(7.037)\end{array}$ & $\begin{array}{l}0.868 \\
(6.564)\end{array}$ & $\begin{array}{l}0.666 \\
(5.173)\end{array}$ & $\begin{array}{l}0.584 \\
(4.560)\end{array}$ & $\begin{array}{l}0.551 \\
(4.216)\end{array}$ & $\begin{array}{l}0.775 \\
(5.950)\end{array}$ \\
\hline Linguistic proximity (ASJP) & $\begin{array}{l}0.097 \\
(3.968)\end{array}$ & $\begin{array}{l}0.104 \\
(3.261)\end{array}$ & $\begin{array}{l}0.078 \\
(2.407)\end{array}$ & $\begin{array}{l}0.104 \\
(3.316)\end{array}$ & $\begin{array}{l}0.073 \\
(2.304)\end{array}$ & $\begin{array}{l}0.112 \\
(3.540)\end{array}$ \\
\hline Common religion & $\begin{array}{l}0.026 \\
(0.328)\end{array}$ & $\begin{array}{l}0.048 \\
(0.427)\end{array}$ & $\begin{array}{l}-0.161 \\
(-1.432)\end{array}$ & $\begin{array}{l}0.037 \\
(0.345)\end{array}$ & $\begin{array}{l}0.149 \\
(1.431)\end{array}$ & $\begin{array}{l}0.170 \\
(1.580)\end{array}$ \\
\hline \multicolumn{7}{|l|}{ Listed } \\
\hline Common official language & $\begin{array}{l}0.193 \\
(3.581)\end{array}$ & $\begin{array}{l}0.238 \\
(3.085)\end{array}$ & $\begin{array}{l}0.285 \\
(3.900)\end{array}$ & $\begin{array}{l}0.241 \\
(3.431)\end{array}$ & $\begin{array}{l}0.149 \\
(2.121)\end{array}$ & $\begin{array}{l}0.132 \\
(1.873)\end{array}$ \\
\hline Common spoken language & $\begin{array}{l}0.643 \\
(7.076)\end{array}$ & $\begin{array}{l}0.527 \\
(4.060)\end{array}$ & $\begin{array}{l}0.608 \\
(4.983)\end{array}$ & $\begin{array}{l}0.659 \\
(5.544)\end{array}$ & $\begin{array}{l}0.635 \\
(5.326)\end{array}$ & $\begin{array}{l}0.701 \\
(5.694)\end{array}$ \\
\hline Common native language & $\begin{array}{l}0.052 \\
(0.389)\end{array}$ & $\begin{array}{l}0.193 \\
(1.030)\end{array}$ & $\begin{array}{l}-0.016 \\
(-0.090)\end{array}$ & $\begin{array}{l}-0.131 \\
(-0.740)\end{array}$ & $\begin{array}{l}0.175 \\
(1.031)\end{array}$ & $\begin{array}{l}0.090 \\
(0.519)\end{array}$ \\
\hline Linguistic proximity (ASJP) & $\begin{array}{l}0.096 \\
(4.545)\end{array}$ & $\begin{array}{l}0.127 \\
(4.545)\end{array}$ & $\begin{array}{l}0.077 \\
(2.824)\end{array}$ & $\begin{array}{l}0.071 \\
(2.642)\end{array}$ & $\begin{array}{l}0.099 \\
(3.886)\end{array}$ & $\begin{array}{l}0.097 \\
(3.665)\end{array}$ \\
\hline Common religion & $\begin{array}{l}0.231 \\
(3.889)\end{array}$ & $\begin{array}{l}0.167 \\
(1.954)\end{array}$ & $\begin{array}{l}0.244 \\
(2.978)\end{array}$ & $\begin{array}{l}0.143 \\
(1.809)\end{array}$ & $\begin{array}{l}0.314 \\
(4.039)\end{array}$ & $\begin{array}{l}0.267 \\
(3.360)\end{array}$ \\
\hline \multicolumn{7}{|l|}{ Differentiated } \\
\hline Common official language & $\begin{array}{l}0.420 \\
(9.298)\end{array}$ & $\begin{array}{l}0.296 \\
(4.605)\end{array}$ & $\begin{array}{l}0.366 \\
(5.949)\end{array}$ & $\begin{array}{l}0.430 \\
(7.238)\end{array}$ & $\begin{array}{l}0.478 \\
(8.056)\end{array}$ & $\begin{array}{l}0.389 \\
(6.520)\end{array}$ \\
\hline Common spoken language & $\begin{array}{l}0.453 \\
(5.812)\end{array}$ & $\begin{array}{l}0.381 \\
(3.428)\end{array}$ & $\begin{array}{l}0.466 \\
(4.367)\end{array}$ & $\begin{array}{l}0.481 \\
(4.606)\end{array}$ & $\begin{array}{l}0.364 \\
(3.582)\end{array}$ & $\begin{array}{l}0.517 \\
(5.003)\end{array}$ \\
\hline Common native language & $\begin{array}{l}0.248 \\
(2.056)\end{array}$ & $\begin{array}{l}0.554 \\
(3.386)\end{array}$ & $\begin{array}{l}0.352 \\
(2.225)\end{array}$ & $\begin{array}{l}0.059 \\
(0.383)\end{array}$ & $\begin{array}{l}0.254 \\
(1.690)\end{array}$ & $\begin{array}{l}0.260 \\
(1.721)\end{array}$ \\
\hline Linguistic proximity (ASJP) & $\begin{array}{l}0.055 \\
(2.984)\end{array}$ & $\begin{array}{l}0.071 \\
(2.971)\end{array}$ & $\begin{array}{l}0.081 \\
(3.379)\end{array}$ & $\begin{array}{l}0.033 \\
(1.424)\end{array}$ & $\begin{array}{l}0.047 \\
(2.050)\end{array}$ & $\begin{array}{l}0.039 \\
(1.667)\end{array}$ \\
\hline Common religion & $\begin{array}{l}0.311 \\
(6.164)\end{array}$ & $\begin{array}{l}0.286 \\
(3.880)\end{array}$ & $\begin{array}{l}0.264 \\
(3.681)\end{array}$ & $\begin{array}{l}0.365 \\
(5.396)\end{array}$ & $\begin{array}{l}0.302 \\
(4.454)\end{array}$ & $\begin{array}{l}0.371 \\
(5.455)\end{array}$ \\
\hline
\end{tabular}

Panel estimations include a set of exporter/year and importer/year fixed effects. The cross-section estimations include a set of exporter and importer fixed effects. Student $t$ s are in parentheses. These are based on robust standard errors that are adjusted for clustering by country-pair in the case of panel estimations. 
Table 6: Common language

Regressand: log of bilateral trade (Rauch categories)

\begin{tabular}{|c|c|c|c|}
\hline & Homogeneous goods & Listed goods & $\begin{array}{l}\text { Differentiated } \\
\text { goods }\end{array}$ \\
\hline \multirow[t]{2}{*}{ Common official language } & 0.023 & 0.194 & 0.420 \\
\hline & $(0.346)$ & $(3.593)$ & $(9.309)$ \\
\hline \multirow[t]{2}{*}{ Common spoken language } & 0.726 & 0.643 & 0.453 \\
\hline & $(7.530)$ & $(7.076)$ & $(5.805)$ \\
\hline \multirow[t]{2}{*}{ Common native language } & & 0.043 & 0.239 \\
\hline & & $(0.316)$ & $(1.972)$ \\
\hline \multirow[t]{2}{*}{ Linguistic proximity (>median) } & 0.171 & 0.136 & 0.076 \\
\hline & $(4.713)$ & $(4.302)$ & $(2.794)$ \\
\hline \multirow[t]{2}{*}{ Linguistic proximity (<median) } & 0.232 & 0.036 & 0.014 \\
\hline & $(5.321)$ & $(1.094)$ & $(0.505)$ \\
\hline \multirow[t]{2}{*}{ Distance $(\log )$} & -1.192 & -1.408 & -1.408 \\
\hline & $(-51.252)$ & $(-79.884)$ & $(-90.781)$ \\
\hline \multirow[t]{2}{*}{ Common border } & 0.654 & 0.747 & 0.762 \\
\hline & $(7.200)$ & $(8.654)$ & $(8.960)$ \\
\hline \multirow[t]{2}{*}{ Ex colonizer/colony } & 1.426 & 1.331 & 1.442 \\
\hline & $(11.226)$ & $(12.112)$ & $(13.974)$ \\
\hline \multirow[t]{2}{*}{ Common colonizer } & 0.551 & 0.837 & 0.812 \\
\hline & $(8.111)$ & $(15.944)$ & (18.174) \\
\hline \multirow[t]{2}{*}{ Common religion } & 0.091 & 0.226 & 0.306 \\
\hline & $(1.138)$ & $(3.771)$ & $(6.005)$ \\
\hline \multirow[t]{2}{*}{ Common legal system } & 0.490 & 0.223 & 0.020 \\
\hline & $(8.644)$ & $(5.385)$ & $(0.542)$ \\
\hline \multirow[t]{2}{*}{ Years at war } & 0.517 & 0.305 & 0.127 \\
\hline & $(2.705)$ & $(1.790)$ & $(0.755)$ \\
\hline Observations & 118377 & 157581 & 195163 \\
\hline Adjusted $\mathrm{R}^{2}$ & 0.577 & 0.710 & 0.782 \\
\hline Number of clusters & 18861 & 23625 & 27853 \\
\hline
\end{tabular}

All regressions contain exporter/year and importer/year fixed effects. Student $t$ s are in parentheses. These are based on robust standard errors that have been adjusted for clustering by country pair. 
Table 7: Common language index (panel estimates)

\begin{tabular}{lllll}
\hline & Total & $\begin{array}{l}\text { Homogeneous } \\
\text { goods }\end{array}$ & Listed goods & $\begin{array}{l}\text { Differentiated } \\
\text { goods }\end{array}$ \\
\hline Common language index & 1.153 & 0.676 & 1.051 & 1.237 \\
& $(14.468)$ & $(5.595)$ & $(11.986)$ & $(15.642)$ \\
Distance (log) & -1.362 & -1.208 & -1.412 & -1.406 \\
& $(-85.788)$ & $(-52.175)$ & $(-80.128)$ & $(-89.967)$ \\
Common border & 0.689 & 0.702 & 0.777 & 0.780 \\
& $(8.074)$ & $(7.725)$ & $(9.032)$ & $(9.201)$ \\
Ex colonizer/colony & 1.624 & 1.507 & 1.424 & 1.622 \\
& $(15.574)$ & $(12.097)$ & $(12.790)$ & $(15.514)$ \\
Common colonizer & 0.868 & 0.584 & 0.903 & 0.919 \\
& $(19.737)$ & $(8.709)$ & $(17.613)$ & $(21.319)$ \\
Common religion & 0.314 & 0.106 & 0.280 & 0.338 \\
& $(6.116)$ & $(1.334)$ & $(4.712)$ & $(6.738)$ \\
Common legal system & 0.225 & 0.444 & 0.187 & 0.039 \\
& $(6.275)$ & $(7.804)$ & $(4.626)$ & $(1.092)$ \\
Years at war & -0.365 & 0.528 & 0.331 & 0.147 \\
& $(-2.196)$ & $(2.795)$ & $(1.969)$ & $(0.875)$ \\
\hline Observations & 209276 & 118377 & 157581 & 195163 \\
Adjusted R ${ }^{2}$ & 0.756 & 0.575 & 0.710 & 0.781 \\
Number of clusters & 28950 & 18861 & 23625 & 27853 \\
\hline All regressions contain exporter/year and importer/year fixed effects. Student & ts are in parentheses. These are based on \\
robust standard errors that have been adjusted for clustering by country pair. & & & \\
\hline
\end{tabular}


Table 8a: Common language with Migration (log)

Regressand: log of bilateral trade (Total trade, panel and yearly estimates)

\begin{tabular}{|c|c|c|c|c|c|c|}
\hline & Panel & 1999 & 2001 & 2003 & 2005 & 2007 \\
\hline Common official language & $\begin{array}{l}0.283 \\
(5.899)\end{array}$ & $\begin{array}{l}0.184 \\
(2.702)\end{array}$ & $\begin{array}{l}0.246 \\
(3.807)\end{array}$ & $\begin{array}{l}0.349 \\
(5.691)\end{array}$ & $\begin{array}{l}0.313 \\
(5.039)\end{array}$ & $\begin{array}{l}0.234 \\
(3.731)\end{array}$ \\
\hline Common spoken language & $\begin{array}{l}0.339 \\
(4.112)\end{array}$ & $\begin{array}{l}0.388 \\
(3.404)\end{array}$ & $\begin{array}{l}0.323 \\
(2.962)\end{array}$ & $\begin{array}{l}0.270 \\
(2.506)\end{array}$ & $\begin{array}{l}0.261 \\
(2.437)\end{array}$ & $\begin{array}{l}0.481 \\
(4.457)\end{array}$ \\
\hline Common native language & $\begin{array}{l}0.131 \\
(1.072)\end{array}$ & $\begin{array}{l}0.260 \\
(1.572)\end{array}$ & $\begin{array}{l}0.177 \\
(1.132)\end{array}$ & $\begin{array}{l}0.027 \\
(0.173)\end{array}$ & $\begin{array}{l}0.212 \\
(1.370)\end{array}$ & $\begin{array}{l}0.112 \\
(0.724)\end{array}$ \\
\hline Linguistic proximity (ASJP) & $\begin{array}{l}0.064 \\
(3.528)\end{array}$ & $\begin{array}{l}0.074 \\
(3.169)\end{array}$ & $\begin{array}{l}0.061 \\
(2.561)\end{array}$ & $\begin{array}{l}0.051 \\
(2.209)\end{array}$ & $\begin{array}{l}0.061 \\
(2.628)\end{array}$ & $\begin{array}{l}0.066 \\
(2.790)\end{array}$ \\
\hline Migration (log) & $\begin{array}{l}0.180 \\
(24.185)\end{array}$ & $\begin{array}{l}0.183 \\
(18.321)\end{array}$ & $\begin{array}{l}0.177 \\
(18.503)\end{array}$ & $\begin{array}{l}0.191 \\
(20.465)\end{array}$ & $\begin{array}{l}0.173 \\
(18.183)\end{array}$ & $\begin{array}{l}0.167 \\
(17.340)\end{array}$ \\
\hline Distance (log) & $\begin{array}{l}-1.189 \\
(-65.998)\end{array}$ & $\begin{array}{l}-1.145 \\
(-46.966)\end{array}$ & $\begin{array}{l}-1.168 \\
(-49.560)\end{array}$ & $\begin{array}{l}-1.208 \\
(-52.611)\end{array}$ & $\begin{array}{l}-1.234 \\
(-53.165)\end{array}$ & $\begin{array}{l}-1.208 \\
(-50.880)\end{array}$ \\
\hline Common border & $\begin{array}{l}0.332 \\
(3.932)\end{array}$ & $\begin{array}{l}0.354 \\
(3.534)\end{array}$ & $\begin{array}{l}0.326 \\
(3.511)\end{array}$ & $\begin{array}{l}0.367 \\
(3.622)\end{array}$ & $\begin{array}{l}0.401 \\
(4.055)\end{array}$ & $\begin{array}{l}0.319 \\
(2.975)\end{array}$ \\
\hline Ex colonizer/colony & $\begin{array}{l}1.118 \\
(11.259)\end{array}$ & $\begin{array}{l}1.230 \\
(11.166)\end{array}$ & $\begin{array}{l}1.105 \\
(9.827)\end{array}$ & $\begin{array}{l}1.070 \\
(9.631)\end{array}$ & $\begin{array}{l}1.087 \\
(9.727)\end{array}$ & $\begin{array}{l}0.988 \\
(8.842)\end{array}$ \\
\hline Common colonizer & $\begin{array}{l}0.673 \\
(14.019)\end{array}$ & $\begin{array}{l}0.674 \\
(9.366)\end{array}$ & $\begin{array}{l}0.623 \\
(9.499)\end{array}$ & $\begin{array}{l}0.643 \\
(10.460)\end{array}$ & $\begin{array}{l}0.694 \\
(11.453)\end{array}$ & $\begin{array}{l}0.685 \\
(11.196)\end{array}$ \\
\hline Common religion & $\begin{array}{l}0.200 \\
(3.767)\end{array}$ & $\begin{array}{l}0.212 \\
(2.808)\end{array}$ & $\begin{array}{l}0.156 \\
(2.139)\end{array}$ & $\begin{array}{l}0.233 \\
(3.311)\end{array}$ & $\begin{array}{l}0.219 \\
(3.100)\end{array}$ & $\begin{array}{l}0.286 \\
(4.029)\end{array}$ \\
\hline Common legal system & $\begin{array}{l}0.204 \\
(5.376)\end{array}$ & $\begin{array}{l}0.190 \\
(3.608)\end{array}$ & $\begin{array}{l}0.199 \\
(3.874)\end{array}$ & $\begin{array}{l}0.204 \\
(4.087)\end{array}$ & $\begin{array}{l}0.212 \\
(4.272)\end{array}$ & $\begin{array}{l}0.276 \\
(5.552)\end{array}$ \\
\hline Years at war & $\begin{array}{l}-0.574 \\
(-3.617)\end{array}$ & $\begin{array}{l}-0.652 \\
(-3.995)\end{array}$ & $\begin{array}{l}-0.564 \\
(-3.583)\end{array}$ & $\begin{array}{l}-0.509 \\
(-2.821)\end{array}$ & $\begin{array}{l}-0.525 \\
(-2.963)\end{array}$ & $\begin{array}{l}-0.550 \\
(-2.995)\end{array}$ \\
\hline Observations & 190,228 & 17,169 & 18,703 & 19,771 & 20,278 & 20,402 \\
\hline $\begin{array}{l}\text { Adjusted } \mathrm{R}^{2} \\
\text { Number of clusters }\end{array}$ & $\begin{array}{l}0.766 \\
24898\end{array}$ & 0.762 & 0.760 & 0.765 & 0.766 & 0.771 \\
\hline \multicolumn{7}{|c|}{$\begin{array}{l}\text { Panel estimations include a set of exporter/year and importer/year fixed effects. The cross-section } \\
\text { estimations include a set of exporter and importer fixed effects. Student ts are in parentheses. These are } \\
\text { based on robust standard errors that are adjusted for clustering by country pair in the case of panel } \\
\text { estimations. }\end{array}$} \\
\hline
\end{tabular}


Table 8b: Common language with Migration (log)

Regressand: log of bilateral trade (Rauch categories)

\begin{tabular}{|c|c|c|c|c|c|c|}
\hline & Panel & 1999 & 2001 & 2003 & 2005 & 2007 \\
\hline \multicolumn{7}{|l|}{ Homogenous } \\
\hline Common official language & $\begin{array}{l}-0.007 \\
(-0.099)\end{array}$ & $\begin{array}{l}0.039 \\
(0.407)\end{array}$ & $\begin{array}{l}-0.105 \\
(-1.120)\end{array}$ & $\begin{array}{l}0.070 \\
(0.765)\end{array}$ & $\begin{array}{l}0.016 \\
(0.175)\end{array}$ & $\begin{array}{l}-0.043 \\
(-0.453)\end{array}$ \\
\hline Common spoken language & $\begin{array}{l}0.556 \\
(5.660)\end{array}$ & $\begin{array}{l}0.731 \\
(5.464)\end{array}$ & $\begin{array}{l}0.549 \\
(4.190)\end{array}$ & $\begin{array}{l}0.470 \\
(3.613)\end{array}$ & $\begin{array}{l}0.441 \\
(3.317)\end{array}$ & $\begin{array}{l}0.654 \\
(4.899)\end{array}$ \\
\hline Linguistic proximity (ASJP) & $\begin{array}{l}0.088 \\
(3.693)\end{array}$ & $\begin{array}{l}0.098 \\
(3.121)\end{array}$ & $\begin{array}{l}0.079 \\
(2.480)\end{array}$ & $\begin{array}{l}0.094 \\
(3.033)\end{array}$ & $\begin{array}{l}0.066 \\
(2.109)\end{array}$ & $\begin{array}{l}0.105 \\
(3.346)\end{array}$ \\
\hline Migration (log) & $\begin{array}{l}0.153 \\
(14.240)\end{array}$ & $\begin{array}{l}0.152 \\
(9.967)\end{array}$ & $\begin{array}{l}0.153 \\
(10.255)\end{array}$ & $\begin{array}{l}0.164 \\
(11.363)\end{array}$ & $\begin{array}{l}0.137 \\
(9.524)\end{array}$ & $\begin{array}{l}0.151 \\
(10.242)\end{array}$ \\
\hline Common religion & $\begin{array}{l}-0.077 \\
(-0.972)\end{array}$ & $\begin{array}{l}-0.014 \\
(-0.122)\end{array}$ & $\begin{array}{l}-0.281 \\
(-2.484)\end{array}$ & $\begin{array}{l}-0.074 \\
(-0.674)\end{array}$ & $\begin{array}{l}0.069 \\
(0.652)\end{array}$ & $\begin{array}{l}0.059 \\
(0.542)\end{array}$ \\
\hline \multicolumn{7}{|l|}{ Listed } \\
\hline Common official language & $\begin{array}{l}0.140 \\
(2.548)\end{array}$ & $\begin{array}{l}0.176 \\
(2.270)\end{array}$ & $\begin{array}{l}0.241 \\
(3.239)\end{array}$ & $\begin{array}{l}0.147 \\
(2.083)\end{array}$ & $\begin{array}{l}0.086 \\
(1.208)\end{array}$ & $\begin{array}{l}0.076 \\
(1.064)\end{array}$ \\
\hline Common spoken language & $\begin{array}{l}0.483 \\
(5.297)\end{array}$ & $\begin{array}{l}0.407 \\
(3.128)\end{array}$ & $\begin{array}{l}0.463 \\
(3.791)\end{array}$ & $\begin{array}{l}0.490 \\
(4.159)\end{array}$ & $\begin{array}{l}0.472 \\
(3.916)\end{array}$ & $\begin{array}{l}0.553 \\
(4.469)\end{array}$ \\
\hline Common native language & $\begin{array}{l}0.003 \\
(0.021)\end{array}$ & $\begin{array}{l}0.106 \\
(0.563)\end{array}$ & $\begin{array}{l}-0.066 \\
(-0.371)\end{array}$ & $\begin{array}{l}-0.111 \\
(-0.647)\end{array}$ & $\begin{array}{l}0.108 \\
(0.631)\end{array}$ & $\begin{array}{l}0.032 \\
(0.180)\end{array}$ \\
\hline Linguistic proximity (ASJP) & $\begin{array}{l}0.081 \\
(3.970)\end{array}$ & $\begin{array}{l}0.111 \\
(4.064)\end{array}$ & $\begin{array}{l}0.065 \\
(2.432)\end{array}$ & $\begin{array}{l}0.058 \\
(2.260)\end{array}$ & $\begin{array}{l}0.074 \\
(2.976)\end{array}$ & $\begin{array}{l}0.081 \\
(3.130)\end{array}$ \\
\hline Migration (log) & $\begin{array}{l}0.178 \\
(21.818)\end{array}$ & $\begin{array}{l}0.176 \\
(15.650)\end{array}$ & $\begin{array}{l}0.166 \\
(15.448)\end{array}$ & $\begin{array}{l}0.194 \\
(18.801)\end{array}$ & $\begin{array}{l}0.178 \\
(17.149)\end{array}$ & $\begin{array}{l}0.174 \\
(16.495)\end{array}$ \\
\hline Common religion & $\begin{array}{l}0.216 \\
(5.161)\end{array}$ & $\begin{array}{l}0.066 \\
(1.106)\end{array}$ & $\begin{array}{l}0.133 \\
(2.315)\end{array}$ & $\begin{array}{l}0.196 \\
(3.492)\end{array}$ & $\begin{array}{l}0.271 \\
(4.828)\end{array}$ & $\begin{array}{l}0.423 \\
(7.454)\end{array}$ \\
\hline \multicolumn{7}{|l|}{ Differentiated } \\
\hline Common official language & $\begin{array}{l}0.352 \\
(7.676)\end{array}$ & $\begin{array}{l}0.214 \\
(3.324)\end{array}$ & $\begin{array}{l}0.321 \\
(5.169)\end{array}$ & $\begin{array}{l}0.370 \\
(6.190)\end{array}$ & $\begin{array}{l}0.382 \\
(6.354)\end{array}$ & $\begin{array}{l}0.333 \\
(5.531)\end{array}$ \\
\hline Common spoken language & $\begin{array}{l}0.400 \\
(5.088)\end{array}$ & $\begin{array}{l}0.342 \\
(3.084)\end{array}$ & $\begin{array}{l}0.387 \\
(3.611)\end{array}$ & $\begin{array}{l}0.414 \\
(3.923)\end{array}$ & $\begin{array}{l}0.293 \\
(2.837)\end{array}$ & $\begin{array}{l}0.492 \\
(4.679)\end{array}$ \\
\hline Common native language & $\begin{array}{l}0.068 \\
(0.559)\end{array}$ & $\begin{array}{l}0.391 \\
(2.397)\end{array}$ & $\begin{array}{l}0.217 \\
(1.383)\end{array}$ & $\begin{array}{l}-0.062 \\
(-0.399)\end{array}$ & $\begin{array}{l}0.069 \\
(0.450)\end{array}$ & $\begin{array}{l}0.017 \\
(0.109)\end{array}$ \\
\hline Linguistic proximity (ASJP) & $\begin{array}{l}0.037 \\
(2.074)\end{array}$ & $\begin{array}{l}0.063 \\
(2.749)\end{array}$ & $\begin{array}{l}0.060 \\
(2.590)\end{array}$ & $\begin{array}{l}0.027 \\
(1.220)\end{array}$ & $\begin{array}{l}0.020 \\
(0.876)\end{array}$ & $\begin{array}{l}0.023 \\
(1.000)\end{array}$ \\
\hline Migration (log) & $\begin{array}{l}0.201 \\
(27.828)\end{array}$ & $\begin{array}{l}0.207 \\
(21.375)\end{array}$ & $\begin{array}{l}0.201 \\
(21.595)\end{array}$ & $\begin{array}{l}0.205 \\
(22.340)\end{array}$ & $\begin{array}{l}0.196 \\
(21.230)\end{array}$ & $\begin{array}{l}0.193 \\
(20.810)\end{array}$ \\
\hline Common religion & $\begin{array}{l}0.202 \\
(3.920)\end{array}$ & $\begin{array}{l}0.184 \\
(2.492)\end{array}$ & $\begin{array}{l}0.159 \\
(2.185)\end{array}$ & $\begin{array}{l}0.240 \\
(3.505)\end{array}$ & $\begin{array}{l}0.178 \\
(2.582)\end{array}$ & $\begin{array}{l}0.296 \\
(4.295)\end{array}$ \\
\hline
\end{tabular}

Panel estimations include a set of exporter/year and importer/year fixed effects. The cross-section estimations include a set of exporter and importer fixed effects. Student $t$ s are in parentheses. These are based on robust standard errors that are adjusted for clustering by country pair in the case of panel estimations. 


\begin{tabular}{|c|c|c|c|}
\hline Common official language & & $\begin{array}{l}0.405 \\
(5.643)\end{array}$ & $\begin{array}{l}0.233 \\
(4.198)\end{array}$ \\
\hline Common spoken language & & $\begin{array}{l}1.244 \\
(8.545)\end{array}$ & $\begin{array}{l}0.439 \\
(4.903)\end{array}$ \\
\hline Common native language & & $\begin{array}{l}-0.379 \\
(-2.240)\end{array}$ & $\begin{array}{l}0.350 \\
(2.463)\end{array}$ \\
\hline Linguistic proximity (ASJP) & & $\begin{array}{l}0.060 \\
(2.892)\end{array}$ & $\begin{array}{l}0.115 \\
(5.053)\end{array}$ \\
\hline $\begin{array}{l}\text { Common official language: English or } \\
\text { (column 3) other major European }\end{array}$ & $\begin{array}{l}0.084 \\
(1.416)\end{array}$ & $\begin{array}{l}-0.237 \\
(-2.658)\end{array}$ & $\begin{array}{l}0.449 \\
(4.807)\end{array}$ \\
\hline $\begin{array}{l}\text { Common spoken language: English or } \\
\text { (column 3) other major European }\end{array}$ & $\begin{array}{l}-0.034 \\
(-0.344)\end{array}$ & $\begin{array}{l}-1.447 \\
(-8.377)\end{array}$ & $\begin{array}{l}-0.656 \\
(-3.164)\end{array}$ \\
\hline $\begin{array}{l}\text { Common native language: English or } \\
\text { (column 3) other major European }\end{array}$ & $\begin{array}{l}-0.001 \\
(-0.007)\end{array}$ & $\begin{array}{l}0.763 \\
(3.173)\end{array}$ & $\begin{array}{l}0.085 \\
(0.349)\end{array}$ \\
\hline $\begin{array}{l}\text { Linguistic proximity (ASJP): English or } \\
\text { (column 3) other major European }\end{array}$ & $\begin{array}{l}0.092 \\
(2.887)\end{array}$ & $\begin{array}{l}0.083 \\
(2.316)\end{array}$ & $\begin{array}{l}-0.075 \\
(-3.038)\end{array}$ \\
\hline Distance $(\log )$ & $\begin{array}{l}-1.418 \\
(-91.968)\end{array}$ & $\begin{array}{l}-1.344 \\
(-83.993)\end{array}$ & $\begin{array}{l}-1.369 \\
(-84.907)\end{array}$ \\
\hline Common border & $\begin{array}{l}0.749 \\
(8.694)\end{array}$ & $\begin{array}{l}0.622 \\
(7.206)\end{array}$ & $\begin{array}{l}0.654 \\
(7.646)\end{array}$ \\
\hline Ex colonizer/colony & $\begin{array}{l}1.742 \\
(16.223)\end{array}$ & $\begin{array}{l}1.445 \\
(14.446)\end{array}$ & $\begin{array}{l}1.451 \\
(13.980)\end{array}$ \\
\hline Common colonizer & $\begin{array}{l}0.884 \\
(19.627)\end{array}$ & $\begin{array}{l}0.758 \\
(16.628)\end{array}$ & $\begin{array}{l}0.755 \\
(16.459)\end{array}$ \\
\hline Common religion & $\begin{array}{l}0.533 \\
(10.695)\end{array}$ & $\begin{array}{l}0.241 \\
(4.644)\end{array}$ & $\begin{array}{l}0.326 \\
(6.242)\end{array}$ \\
\hline Common legal system & $\begin{array}{l}0.422 \\
(10.427)\end{array}$ & $\begin{array}{l}0.338 \\
(8.172)\end{array}$ & $\begin{array}{l}0.267 \\
(6.954)\end{array}$ \\
\hline Years at war & $\begin{array}{l}-0.437 \\
(-2.615)\end{array}$ & $\begin{array}{l}-0.402 \\
(-2.426)\end{array}$ & $\begin{array}{l}-0.388 \\
(-2.336)\end{array}$ \\
\hline Observations & 209276 & 209276 & 209276 \\
\hline Adjusted $\mathrm{R}^{2}$ & 0.755 & 0.758 & 0.757 \\
\hline Number of clusters & 28950 & 28950 & 28950 \\
\hline
\end{tabular}

All regressions contain exporter/year and importer/year fixed effects. Student $t$ s are in parentheses. These are based on robust standard errors that have been adjusted for clustering by country pair. 
Table A1. The language data (CSL and CNL: percentage of population $\geq 4 \%$ )

\begin{tabular}{|c|c|c|c|c|}
\hline Country & COL & CSL & CNL & LP \\
\hline Afghanistan & $\begin{array}{l}\text { Persian } \\
\text { (Farsi) }\end{array}$ & $\begin{array}{l}\text { Persian (Farsi) .5, } \\
\text { Pashto.32, Uzbek .09 }\end{array}$ & $\begin{array}{l}\text { Persian (Farsi) .3, Pashto } .32 \\
\text { Uzbek .09 }\end{array}$ & $\begin{array}{l}\text { Chaman Pashto } .5 \text {, } \\
\text { Persian } .5\end{array}$ \\
\hline Albania & & Albanian .95 & Albanian .95 & Albanian Tosk 1 \\
\hline Algeria & $\begin{array}{l}\text { French, } \\
\text { Arabic }\end{array}$ & Arabic .7, French .57 & Arabic .62 & Standard Arabic 1 \\
\hline Andorra & $\begin{array}{l}\text { French, } \\
\text { Spanish }\end{array}$ & $\begin{array}{l}\text { French .72, Spanish .69, } \\
\text { English } .22\end{array}$ & French .49 , Spanish .35 & $\begin{array}{l}\text { French } .58, \text { Spanish } \\
.42\end{array}$ \\
\hline Angola & Portuguese & Portuguese .8 & Portuguese .6 & Portuguese 1 \\
\hline Anguilla & English & English .92 & English .92 & English 1 \\
\hline $\begin{array}{l}\text { Antigua and } \\
\text { Barbuda }\end{array}$ & English & English .8 & English .78 & English 1 \\
\hline Argentina & Spanish & $\begin{array}{l}\text { Spanish .99, German .04, } \\
\text { Italian .04 }\end{array}$ & Spanish .96, Italian .04 & Spanish 1 \\
\hline Armenia & & $\begin{array}{l}\text { Armenian 1, Russian .09, } \\
\text { Turkish } .05\end{array}$ & Armenian 1, Turkish .05 & Eastern Armenian 1 \\
\hline Aruba & Dutch & $\begin{array}{l}\text { Spanish } .75 \text {, } \\
\text { English } .42 \text {, Dutch } .07\end{array}$ & $\begin{array}{l}\text { English } .09 \text {, } \\
\text { Spanish } .07 \text {, Dutch } .07\end{array}$ & Papiamento 1 \\
\hline Australia & English & English .97 & English .7 & English 1 \\
\hline Austria & German & $\begin{array}{l}\text { German 1, English } .58 \text {, French } \\
.1 \text {, Italian } .08 \text {, Spanish } .04\end{array}$ & German .96 & Standard German 1 \\
\hline Azerbaijan & Turkish & Turkish .98, Russian .06 & Turkish .76, Russian .06 & Turkish 1 \\
\hline Bahamas & English & English .87 & English .79 & English 1 \\
\hline Bahrain & Arabic & Arabic .87 , Persian (Farsi) .06 & Arabic .55, Persian (Farsi) .06 & Standard Arabic 1 \\
\hline Bangladesh & & Bengali .98 & Bengali .72 & Bengali 1 \\
\hline Barbados & English & English .99 & English .94 & English 1 \\
\hline Belarus & Russian & Russian .96, Polish .04 & Russian .96 Polish .04 & Ninilchik Russian 1 \\
\hline $\begin{array}{l}\text { Belgium and } \\
\text { Luxembourg }\end{array}$ & $\begin{array}{l}\text { French, } \\
\text { Dutch, } \\
\text { German }\end{array}$ & $\begin{array}{l}\text { French } .869, \text { Dutch } .6461 \text {, } \\
\text { English } .59 \text {, German } .33 \text {, } \\
\text { Spanish } .06 \text {, Italian } .05\end{array}$ & Dutch .51 , French .35 & $\begin{array}{l}\text { Brabantic (Dutch) } \\
.57, \text { French } .43\end{array}$ \\
\hline Belize & English & English .82, Spanish .43 & English .63, Spanish .36 & $\begin{array}{l}\text { English .64, Spanish } \\
.36\end{array}$ \\
\hline Benin & French & French .26 & & None \\
\hline Bermuda & English & English .97, Portuguese .04 & English .97, Portuguese .04 & English 1 \\
\hline Bhutan & & Nepali .38, English .11 & Nepali .38 & $\begin{array}{l}\text { Tibetan Central .55, } \\
\text { Nepali } .45\end{array}$ \\
\hline
\end{tabular}


Table A1: The language data (Continued)

\begin{tabular}{|c|c|c|c|c|}
\hline Country & COL & CSL & CNL & $\mathbf{L P}$ \\
\hline Bolivia & Spanish & Spanish .88, Quechua .36 & Spanish .42, Quechua .36 & $\begin{array}{l}\text { Spanish .54, Quechua } \\
\text { Huaylas Ancash .46 }\end{array}$ \\
\hline \multicolumn{2}{|c|}{ Bosnia and Herzegovina } & $\begin{array}{l}\text { Bosnian .48, English } .45 \text {, } \\
\text { Serbian } .36 \text {, Russian } .4\end{array}$ & Bosnian .48, Serbian .36 & $\begin{array}{l}\text { Bosnian .57, } \\
\text { Serbocroatian .43 }\end{array}$ \\
\hline Brazil & Portuguese & Portuguese 1, Spanish .06 & Portuguese .99 & Portuguese 1 \\
\hline $\begin{array}{l}\text { British Virgin } \\
\text { Islands }\end{array}$ & English & English 1 & English 1 & English 1 \\
\hline Brunei & Malay & Malay .91, English .38 & Malay .91 & Malay 1 \\
\hline Bulgaria & Bulgarian & $\begin{array}{l}\text { Bulgarian, 1, Russian .35, } \\
\text { English .23, German .12, } \\
\text { Turkish .1, French .09 }\end{array}$ & Bulgarian .84, Turkish .08 & Bulgarian 1 \\
\hline Burkina Faso & French & French .05 & & None \\
\hline Burundi & French & French .08 & & $\begin{array}{l}\text { Kinyarwanda } 1 \\
\text { (Rundi) }\end{array}$ \\
\hline Cambodia & & & & Khmer 1 \\
\hline Cameroon & $\begin{array}{l}\text { French, } \\
\text { English }\end{array}$ & $\begin{array}{l}\text { French } .45 \text {, English } .42 \text {, } \\
\text { Fulfulde } .3 \text {, Fang } .05\end{array}$ & Fulfulde .3 , Fang .05 & None \\
\hline Canada & $\begin{array}{l}\text { English, } \\
\text { French }\end{array}$ & English .85 , French .35 & English .53, French .23 & English .7, French .3 \\
\hline Cape Verde & Portuguese & Portuguese .77 & Portuguese .77 & Portuguese 1 \\
\hline $\begin{array}{l}\text { Cayman } \\
\text { Islands }\end{array}$ & English & English .98, Spanish .05 & English .43, Spanish .05 & English 1 \\
\hline $\begin{array}{l}\text { Central } \\
\text { African } \\
\text { Republic }\end{array}$ & French & French .23 & & None \\
\hline Chad & $\begin{array}{l}\text { French, } \\
\text { Arabic }\end{array}$ & Arabic .26 , French .2 & Arabic .09 & None \\
\hline Chile & Spanish & Spanish .99 & Spanish .89 & Spanish 1 \\
\hline China & Chinese & Chinese .88 & Chinese .88 & Mandarin 1 (Chinese) \\
\hline Colombia & Spanish & Spanish .99 & Spanish .99 & Spanish 1 \\
\hline Comoros & $\begin{array}{l}\text { French, } \\
\text { Arabic }\end{array}$ & Arabic .57 , French .47 & & $\begin{array}{l}\text { Swahili Mwani } 1 \\
\text { (Comorian) }\end{array}$ \\
\hline Cook Islands & English & English .2 & English .05 & None \\
\hline Costa Rica & Spanish & Spanish .99 & Spanish .96 & Spanish 1 \\
\hline Croatia & & $\begin{array}{l}\text { Croatian .99, English .49, } \\
\text { French .04, German .34, } \\
\text { Italian .14, Russian .04 }\end{array}$ & Croatian .99 & Croatian 1 \\
\hline Cuba & Spanish & Spanish .99 & Spanish .99 & Spanish 1 \\
\hline Cyprus & Greek & $\begin{array}{l}\text { Greek .79, English .76, } \\
\text { Turkish .2, French .12, } \\
\text { German .05, Italian .04 }\end{array}$ & Greek .79,Turkish .2 & Greek .79, Turkish .21 \\
\hline
\end{tabular}


Table A1: The language data (Continued)

\begin{tabular}{|c|c|c|c|c|}
\hline Country & COL & CSL & CNL & $\mathbf{L P}$ \\
\hline \multicolumn{2}{|c|}{ Czech Republic } & $\begin{array}{l}\text { Czech .98, German .28, } \\
\text { English .24, Russian .2 }\end{array}$ & Czech .98 & Czech 1 \\
\hline $\begin{array}{l}\text { Democratic } \\
\text { Republic of } \\
\text { the Congo }\end{array}$ & French & $\begin{array}{l}\text { French } .4 \text {, Swahili } .17 \text {, } \\
\text { Lingala } .12\end{array}$ & Swahili .17, Lingala .12 & None \\
\hline Denmark & Danish & $\begin{array}{l}\text { Danish 1, English .86, German } \\
.58 \text {, French .12, Swedish .11, } \\
\text { Spanish } .05\end{array}$ & Danish .97 & Danish 1 \\
\hline Djibouti & $\begin{array}{l}\text { French, } \\
\text { Arabic }\end{array}$ & Arabic .68, French .2 & Arabic .09 & None \\
\hline Dominica & English & English .94, French .09 & English .04 & French 1 \\
\hline $\begin{array}{l}\text { Dominican } \\
\text { Republic }\end{array}$ & Spanish & Spanish 1 & Spanish .99 & Spanish 1 \\
\hline Ecuador & Spanish & Spanish .98, Quechua .12 & Spanish .93, Quechua .12 & Spanish 1 \\
\hline Egypt & Arabic & Arabic .99 & Arabic .95 & Standard Arabic 1 \\
\hline El Salvador & Spanish & Spanish 1 & Spanish 1 & Spanish 1 \\
\hline Eritrea & & Arabic .59 & Arabic .05 & Tigrinya 1 \\
\hline Estonia & & $\begin{array}{l}\text { Russian .83, English .46, } \\
\text { German .22, Finnish .2 }\end{array}$ & Russian .17 & $\begin{array}{l}\text { Estonian Voro } .83, \\
\text { Ninilchik Russian .17 }\end{array}$ \\
\hline Falkland Isl. & English & English .96 & English .63 & English 1 \\
\hline Fiji & English & Hindi .46, English .21 & Hindi .46 & Hindi .5, Fijian .5 \\
\hline Finland & Swedish & $\begin{array}{l}\text { Finnish .99, English .63, } \\
\text { Swedish .46, German .18 }\end{array}$ & Finnish .94, Swedish .05 & Finnish 1 \\
\hline France & French & $\begin{array}{l}\text { French } .99 \text {, English } .36 \text {, } \\
\text { Spanish } .13 \text {, German } .08 \text {, } \\
\text { Italian } .07\end{array}$ & French .93 & French 1 \\
\hline Gabon & French & French .8, Fang .29 & Fang .29 & None \\
\hline Gambia & English & Fulfulde .17 & Fulfulde .17 & None \\
\hline Georgia & & $\begin{array}{l}\text { Armenian .1, Russian .09, } \\
\text { Turkish .08 }\end{array}$ & Armenian .1, Turkish .08 & Georgian 1 \\
\hline Germany & German & $\begin{array}{l}\text { German .99, English .56, } \\
\text { French .15, Spanish .04, } \\
\text { Russian .11 }\end{array}$ & German .9, Russian .04 & Standard German 1 \\
\hline Ghana & English & English .06 & & None \\
\hline Gibraltar & English & English .96, Spanish .5 & English .93, Spanish .26 & $\begin{array}{l}\text { English .78, Spanish } \\
.22\end{array}$ \\
\hline Greece & Greek & $\begin{array}{l}\text { Greek .99, English .48, } \\
\text { German .09,French .08, Italian } \\
.04\end{array}$ & Greek .99 & Greek 1 \\
\hline Greenland & Danish & Danish .6 & Danish .14 & $\begin{array}{l}\text { Inuktitut } .86 \text { Danish } \\
.14\end{array}$ \\
\hline
\end{tabular}


Table A1: The language data (Continued)

\begin{tabular}{|c|c|c|c|c|}
\hline Country & COL & CSL & CNL & LP \\
\hline Grenada & English & English .91 & English .91 & English 1 \\
\hline Guatemala & Spanish & Spanish .86 & Spanish .65 & Spanish 1 \\
\hline Guinea & French & French .62 & & None \\
\hline $\begin{array}{l}\text { Guinea- } \\
\text { Bissau }\end{array}$ & Portuguese & Portuguese .14 & & None \\
\hline Guyana & English & English .91, Hindi .45 & English .87, Hindi.45 & English 1 \\
\hline Haiti & French & French .8 & French .08 & Haitian Creole 1 \\
\hline Honduras & Spanish & Spanish .99 & Spanish .97 & Spanish 1 \\
\hline Hong Kong & $\begin{array}{l}\text { English, } \\
\text { Chinese }\end{array}$ & Chinese .95 , English .36 & Chinese .95 & Mandarin 1 (Chinese) \\
\hline Hungary & & $\begin{array}{l}\text { Hungarian } 1 \text {, German } .25 \text {, } \\
\text { English } .23 \text {, Russian } .08\end{array}$ & Hungarian 1 & Csango 1 (Hungarian) \\
\hline Iceland & Danish & English .89, Danish .6 & & Danish 1 \\
\hline India & English & $\begin{array}{l}\text { Hindi .46, English } .23 \text {, Bengali } \\
.08 \text {, Tamil .06, Urdu } .05\end{array}$ & $\begin{array}{l}\text { Hindi.46 Bengali } .08 \\
\text { Tamil .06, Urdu .05 }\end{array}$ & None \\
\hline Indonesia & Malay & Malay .58 , Javanese .43 & Javanese .43 Malay .04 & Javanese 1 \\
\hline Iran & $\begin{array}{l}\text { Persian } \\
\text { (Farsi) }\end{array}$ & Persian (Farsi) .65, Turkish .27 & Persian (Farsi) .5, Turkish .2 & $\begin{array}{l}\text { Persian .72, Turkish } \\
.28\end{array}$ \\
\hline Iraq & Arabic & Arabic .64 & Arabic .64 & Standard Arabic 1 \\
\hline Ireland & English & $\begin{array}{l}\text { English .98, French .2, } \\
\text { German } .07\end{array}$ & English .93 & English 1 \\
\hline Israel & English & $\begin{array}{l}\text { English .5, Arabic .21, } \\
\text { Russian .1 }\end{array}$ & Arabic .21, Russian .1 & $\begin{array}{l}\text { Hebrew .87, Ninilchik } \\
\text { Russian } .13\end{array}$ \\
\hline Italy & Italian & $\begin{array}{l}\text { Italian } .96 \text {, English } .29 \text {, French } \\
.14 \text {, German } .05 \text {, Spanish } .04\end{array}$ & Italian .95 & Italian 1 \\
\hline Ivory Coast & French & French .7 & & None \\
\hline Jamaica & English & English .98 & English .96 & English 1 \\
\hline Japan & & English .12 & & Japanese Kyoto 1 \\
\hline Jordan & Arabic & Arabic .98 & Arabic .98 & Standard Arabic 1 \\
\hline Kazakhstan & Russian & $\begin{array}{l}\text { Russian .95, German .06, } \\
\text { Ukrainian } .06\end{array}$ & Russian .41 & $\begin{array}{l}\text { Kazakh } .59 \text {, Ninilchik } \\
\text { Russian } .41\end{array}$ \\
\hline Kenya & $\begin{array}{l}\text { Swahili, } \\
\text { English }\end{array}$ & Swahili .78, English .07 & Swahili .78 & Swahili Chirazi 1 \\
\hline Kiribati & English & English .24 & & Kiribati 1 \\
\hline Kuwait & Arabic & Arabic .98 & Arabic .98 & Standard Arabic 1 \\
\hline Kyrgyzstan & Russian & Russian .95, Uzbek .14 & Russian .27 Uzbek .14 & $\begin{array}{l}\text { Kyrgyz .73, Ninilchik } \\
\text { Russian } .27\end{array}$ \\
\hline Laos & & & & Lu 1 (Lao) \\
\hline
\end{tabular}


Table A1: The language data (Continued)

\begin{tabular}{|c|c|c|c|c|}
\hline Country & COL & CSL & CNL & LP \\
\hline $\begin{array}{l}\text { Latvia } \\
\end{array}$ & & $\begin{array}{l}\text { Russian .96, English .39, } \\
\text { German .19 }\end{array}$ & Russian .26 & $\begin{array}{l}\text { Latvian .74, Ninilchik } \\
\text { Russian .26 }\end{array}$ \\
\hline Lebanon & $\begin{array}{l}\text { French, } \\
\text { Arabic }\end{array}$ & $\begin{array}{l}\text { Arabic } .98, \text { French } .65, \\
\text { English } .25\end{array}$ & Arabic .93 & Standard Arabic 1 \\
\hline Liberia & English & English .83 & English .16 & None \\
\hline Libya & Arabic & Arabic .98 & Arabic .9 & Standard Arabic 1 \\
\hline Lithuania & & $\begin{array}{l}\text { Russian .87, English } .32 \text {, } \\
\text { Polish .2, German } .14\end{array}$ & Russian .07, Polish .05 & Lithuanian 1 \\
\hline Macedonia & Bulgarian & $\begin{array}{l}\text { Bulgarian } .67 \text {, Albanian } .25 \text {, } \\
\text { Turkish } .04\end{array}$ & $\begin{array}{l}\text { Bulgarian .67, Albanian } .25 \text {, } \\
\text { Turkish .04 }\end{array}$ & Bulgarian 1 \\
\hline Madagascar & $\begin{array}{l}\text { French, } \\
\text { English }\end{array}$ & French .2 & & Malagasy Ambositra 1 \\
\hline Malawi & & English .04 & & Lega 1 (Nyanja) \\
\hline Malaysia & Malay & $\begin{array}{l}\text { Malay } .89 \text {, English } .27 \text {, } \\
\text { Chinese } .26 \text {, Tamil } .05\end{array}$ & $\begin{array}{l}\text { Malay } .38 \text {, Chinese } .19 \text {, } \\
\text { Tamil } .05\end{array}$ & $\begin{array}{l}\text { Malay .67, Mandarin } \\
.33 \text { (Chinese) }\end{array}$ \\
\hline Mali & French & French .16, Fulfulde .11 & Fulfulde .11 & None \\
\hline Malta & English & $\begin{array}{l}\text { English } .88 \text {, Italian } .66 \text {, } \\
\text { French } .17\end{array}$ & & Maltese 1 \\
\hline $\begin{array}{l}\text { Marshall } \\
\text { Islands }\end{array}$ & English & English .98 & English .98 & English 1 \\
\hline Mauritania & Arabic & Arabic .93 , Fulfulde .06 & Arabic .93 , Fulfulde .06 & Standard Arabic 1 \\
\hline Mauritius & $\begin{array}{l}\text { French, } \\
\text { English }\end{array}$ & $\begin{array}{l}\text { French .73, English .16, } \\
\text { Urdu .05 }\end{array}$ & Urdu .05, French .04 & Mauritian 1 \\
\hline Mexico & Spanish & Spanish .99, English .05 & Spanish .92 & Spanish 1 \\
\hline Micronesia & English & English .58 & English .04 & None \\
\hline Moldova & Romanian & $\begin{array}{l}\text { Romanian .76, Russian .23, } \\
\text { Bulgarian .1, Ukrainian .05 }\end{array}$ & $\begin{array}{l}\text { Romanian .76, Russian .11, } \\
\text { Bulgarian .1, Ukrainian .05 }\end{array}$ & Romanian 1 \\
\hline Montserrat & English & English .68 & English .68 & English 1 \\
\hline Morocco & $\begin{array}{l}\text { French, } \\
\text { Arabic }\end{array}$ & $\begin{array}{l}\text { Arabic . } 75 \text {, French } .33 \text {, } \\
\text { Spanish } .22\end{array}$ & Arabic .75 & Standard Arabic 1 \\
\hline Mozambique & Portuguese & Portuguese .4 & Portuguese .07 & None \\
\hline Nauru & English & English .97 & English .08 & Nauruan 1 \\
\hline Nepal & & Nepali .57 & Nepali .57 & Nepali 1 \\
\hline Netherlands & Dutch & $\begin{array}{l}\text { Dutch 1, English .87, German } \\
.7 \text {, French } .29 \text {, Spanish .05 }\end{array}$ & Dutch .96 & Brabantic (Dutch) 1 \\
\hline $\begin{array}{l}\text { Netherlands } \\
\text { Antilles }\end{array}$ & Dutch & Spanish .56, Dutch .07 & Dutch .07, Spanish .05 & Papiamento 1 \\
\hline $\begin{array}{l}\text { New } \\
\text { Caledonia }\end{array}$ & French & French .97 & French .23 & French 1 \\
\hline
\end{tabular}


Table A1: The language data (Continued)

\begin{tabular}{|c|c|c|c|c|}
\hline Country & COL & CSL & CNL & LP \\
\hline New Zealand & English & English .98 & English .98 & English 1 \\
\hline Nicaragua & Spanish & Spanish .97 & Spanish .87 & Spanish 1 \\
\hline Niger & French & $\begin{array}{l}\text { Hausa } .5 \text {, Arabic } .29, \\
\text { French } .09 \text {, Fulfulde } .08\end{array}$ & Hausa .5 , Fulfulde .08 & None \\
\hline Nigeria & English & English .53, Hausa .46 & Hausa .46 & None \\
\hline Niue & English & English .74 & English .04 & Niue 1 \\
\hline $\begin{array}{l}\text { Norfolk } \\
\text { Island }\end{array}$ & English & English .79 & English .79 & English 1 \\
\hline $\begin{array}{l}\text { Northern } \\
\text { Mariana } \\
\text { Islands }\end{array}$ & English & English .83 , Chinese .23 & Chinese .23 , English .06 & None \\
\hline Norway & & English .89, Swedish .46 & Swedish .06 & Norwegian Bokmaal 1 \\
\hline Oman & Arabic & Arabic .81 & Arabic .5 & Standard Arabic 1 \\
\hline Pakistan & & $\begin{array}{l}\text { Pashto .12, English } .1 \text {, } \\
\text { Urdu } .07\end{array}$ & Pashto .12, Urdu .07 & $\begin{array}{l}\text { Agra Gujari } 1 \\
\text { (Panjabi) }\end{array}$ \\
\hline Palau & English & English .93, Chinese .06 & Chinese .06 , English .05 & Palauan 1 \\
\hline Panama & Spanish & Spanish .93 & Spanish .77 & Spanish 1 \\
\hline $\begin{array}{l}\text { Papua New } \\
\text { Guinea }\end{array}$ & English & English .5 & & None \\
\hline Paraguay & Spanish & Spanish .7, Portuguese .07 & Portuguese .07 , Spanish .06 & $\begin{array}{l}\text { Chiriguano } 1 \\
\text { (Guarani) }\end{array}$ \\
\hline Peru & Spanish & Spanish .87, Quechua .17 & Spanish .8, Quechua .17 & Spanish 1 \\
\hline Philippines & English & English .55 & English .04 & Tagalog 1 \\
\hline $\begin{array}{l}\text { Pitcairn } \\
\text { Islands }\end{array}$ & English & English .92 & English .92 & English 1 \\
\hline Poland & & $\begin{array}{l}\text { Polish .98, English .29, } \\
\text { Russian .26, German .19 }\end{array}$ & Polish .98 & Polish 1 \\
\hline Portugal & Portuguese & $\begin{array}{l}\text { Portuguese 1, English .32, } \\
\text { French .24, Spanish .09 }\end{array}$ & Portuguese 1 & Portuguese 1 \\
\hline Qatar & Arabic & Arabic .89 , Persian (Farsi) .09 & $\begin{array}{l}\text { Arabic .84, } \\
\text { Persian (Farsi) } .09\end{array}$ & Standard Arabic 1 \\
\hline $\begin{array}{l}\text { Republic of } \\
\text { the Congo }\end{array}$ & French & French .6, Lingala .12 & Lingala .12 & None \\
\hline Romania & Romanian & $\begin{array}{l}\text { Romanian } .92 \text {, English } .29 \text {, } \\
\text { French } .24 \text {, Hungarian } .08 \text {, } \\
\text { German } .06\end{array}$ & $\begin{array}{l}\text { Romanian } .92, \\
\text { Hungarian } .04\end{array}$ & Romanian 1 \\
\hline Russia & Russian & Russian 1, English .05 & Russian, 1 & Ninilchik Russian 1 \\
\hline Rwanda & French & French .09 & & Kinyarwanda 1 \\
\hline Saint Helena & English & English .82 & English .82 & English 1 \\
\hline
\end{tabular}


Table A1: The language data (Continued)

\begin{tabular}{|c|c|c|c|c|}
\hline Country & COL & CSL & CNL & LP \\
\hline $\begin{array}{l}\text { Saint Kitts } \\
\text { and Nevis }\end{array}$ & English & English .78 & English .78 & English 1 \\
\hline Saint Lucia & English & English .43 & English .19 & French 1 \\
\hline $\begin{array}{l}\text { Saint Pierre } \\
\text { and Miquelon }\end{array}$ & French & French 1 & French 1 & French 1 \\
\hline $\begin{array}{l}\text { Saint Vincent } \\
\text { and the } \\
\text { Grenadines }\end{array}$ & English & English .95 & English .95 & English 1 \\
\hline $\begin{array}{l}\text { Sao Tome } \\
\text { and Principe }\end{array}$ & $\begin{array}{l}\text { Portuguese, } \\
\text { French }\end{array}$ & Portuguese .95 , French .65 & Portuguese .5 & Portuguese 1 \\
\hline Saudi Arabia & Arabic & Arabic .89 & Arabic .89 & Standard Arabic 1 \\
\hline Senegal & French & French .31 , Fulfulde .23 & Fulfulde .23 & Wolof 1 \\
\hline Seychelles & $\begin{array}{l}\text { French, } \\
\text { English }\end{array}$ & French .6, English .38 & & Seychelles Creole 1 \\
\hline Sierra Leone & English & English .84 & English .08 & None \\
\hline Singapore & $\begin{array}{l}\text { English, } \\
\text { Chinese }\end{array}$ & $\begin{array}{l}\text { Chinese .74, English .71, } \\
\text { Malay .1 }\end{array}$ & Chinese .44, English .14 & $\begin{array}{l}\text { Mandarin .76 } \\
\text { (Chinese), English .24 }\end{array}$ \\
\hline Slovakia & & $\begin{array}{l}\text { English .32, German .32, } \\
\text { Russian .3, Czech .26, } \\
\text { Hungarian .16 }\end{array}$ & Hungarian .16 & Slovak 1 \\
\hline Slovenia & & $\begin{array}{l}\text { Croatian } .62 \text {, English } .57 \text {, } \\
\text { German } .5 \text {, Italian } .15\end{array}$ & Croatian .62 & Slovenian 1 \\
\hline $\begin{array}{l}\text { Solomon } \\
\text { Islands }\end{array}$ & English & English .32 & & None \\
\hline Somalia & & & & Somali 1 \\
\hline South Africa & $\begin{array}{l}\text { English, } \\
\text { Dutch }\end{array}$ & Dutch .4, English .29 & Dutch .13, English .08 & None \\
\hline South Korea & & & & None \\
\hline Spain & Spanish & $\begin{array}{l}\text { Spanish .99, } \\
\text { English .27, French } .12\end{array}$ & Spanish .89 & Spanish 1 \\
\hline Sri Lanka & & Tamil .18, English .1 & Tamil .18 & Sinhala .8 , Tamil .2 \\
\hline Sudan & Arabic & Arabic .61 & Arabic .41 & Standard Arabic 1 \\
\hline Suriname & Dutch & $\begin{array}{l}\text { English } .87 \text {, Dutch } .84, \\
\text { Hindi } .37 \text {, Javanese } .15\end{array}$ & $\begin{array}{l}\text { Dutch } .6 \text {, English } .55 \\
\text { Hindi } .37 \text { Javanese } .15\end{array}$ & $\begin{array}{l}\text { Brabantic (Dutch) .52, } \\
\text { English } .48\end{array}$ \\
\hline Sweden & Swedish & $\begin{array}{l}\text { Swedish .99, English .89, } \\
\text { German .3, French .11, } \\
\text { Danish .07, Spanish .06 }\end{array}$ & Swedish .95 & Swedish 1 \\
\hline Switzerland & $\begin{array}{l}\text { German, } \\
\text { French }\end{array}$ & $\begin{array}{l}\text { German .73, English .61, } \\
\text { French } .48 \text {, Italian } .07\end{array}$ & $\begin{array}{l}\text { German .64, French } .2 \text {, } \\
\text { Italian } .07\end{array}$ & $\begin{array}{l}\text { Standard German .74, } \\
\text { French } .26\end{array}$ \\
\hline Syria & Arabic & Arabic .92 & Arabic .92 & Standard Arabic 1 \\
\hline
\end{tabular}


Table A1: The language data (Continued)

\begin{tabular}{|c|c|c|c|c|}
\hline Country & COL & CSL & CNL & $\mathbf{L P}$ \\
\hline Taiwan & Chinese & Chinese .98 & Chinese .98 & Mandarin 1 (Chinese) \\
\hline Tajikistan & Russian & $\begin{array}{l}\text { Persian (Farsi) .8, } \\
\text { Russian .5, Uzbek .17 }\end{array}$ & Persian (Farsi) .8, Uzbek .17 & Persian 1 \\
\hline Tanzania & $\begin{array}{l}\text { Swahili, } \\
\text { English }\end{array}$ & $\begin{array}{l}\text { Swahili .93, English .1, } \\
\text { Arabic .1 }\end{array}$ & Swahili .93 & Swahili Chirazi 1 \\
\hline Thailand & & English .1, Malay .04 & Malay .04 & Thai 1 \\
\hline Togo & French & French .33 & & None \\
\hline Tonga & English & English .3 & & Nkoya 1 (Tonga) \\
\hline $\begin{array}{l}\text { Trinidad and } \\
\text { Tobago }\end{array}$ & English & English .88 & English .88 & English 1 \\
\hline Tunisia & $\begin{array}{l}\text { French, } \\
\text { Arabic }\end{array}$ & Arabic .99 , French .64 & Arabic .99 & Standard Arabic 1 \\
\hline Turkey & Turkish & Turkish .99, English .17 & Turkish .93 & Turkish 1 \\
\hline Turkmenistan & Turkish & Turkish .72, Russian .12 & Turkish .72, Russian .07 & Turkish 1 \\
\hline $\begin{array}{l}\text { Turks and } \\
\text { Caicos } \\
\text { Islands }\end{array}$ & English & English .04 & English .04 & English 1 \\
\hline Tuvalu & English & & & $\begin{array}{l}\text { Nanumea } 1 \\
\text { (Tuvaluan) }\end{array}$ \\
\hline Uganda & English & English .08 & & None \\
\hline Ukraine & & Russian .83, Ukrainian .67 & Ukrainian .67, Russian .29 & $\begin{array}{l}\text { Ukrainian .7, } \\
\text { Ninilchik Russian } .3\end{array}$ \\
\hline $\begin{array}{l}\text { United Arab } \\
\text { Emirates }\end{array}$ & Arabic & Arabic .78 & Arabic .77 & Standard Arabic 1 \\
\hline $\begin{array}{l}\text { United } \\
\text { Kingdom }\end{array}$ & English & $\begin{array}{l}\text { English } .99 \text {, French } .23 \text {, } \\
\text { German } .09 \text {, Spanish } .08\end{array}$ & English .92 & English 1 \\
\hline United States & English & English .96, Spanish .16 & English .82, Spanish .15 & $\begin{array}{l}\text { English } .85, \text { Spanish } \\
.15\end{array}$ \\
\hline Uruguay & Spanish & Spanish .99 & Spanish .97 & Spanish 1 \\
\hline Uzbekistan & & $\begin{array}{l}\text { Uzbek .74, Russian .51, } \\
\text { Persian (Farsi) .05 }\end{array}$ & $\begin{array}{l}\text { Uzbek .74, Russian .14, } \\
\text { Persian (Farsi) .05 }\end{array}$ & $\begin{array}{l}\text { Uzbek .84, } \\
\text { Ninilchik Russian .16, }\end{array}$ \\
\hline Vanuatu & $\begin{array}{l}\text { English, } \\
\text { French }\end{array}$ & English .84, French .45 & English .28 & None \\
\hline Venezuela & Spanish & Spanish .99 & Spanish .97 & Spanish 1 \\
\hline Vietnam & & & & Vietnamese 1 \\
\hline Yemen & Arabic & Arabic .95 & Arabic .95 & Standard Arabic 1 \\
\hline Zambia & English & English .16 & & None \\
\hline Zimbabwe & English & English .42 & & Xhosa 1 \\
\hline
\end{tabular}

Notes: The designations of the languages in the LP column are those furnished by Dik Bakker of the ASJP project in response to a list we submitted. Since these designations do not always correspond to the names on our list, and sometimes the language he proposed is 
clearly a very close alternative, in some cases we indicate in parentheses the names of the languages for which we asked. As regards Dominica and St Lucia, where the French Creole language we requested was not in the ASJP databank, we chose to use French instead in constructing LP. This explains why French does not occur as a native language in the CNL column and yet does occur as such in the LP column for both countries. Note also that Comorian, the principal native language of Comoros, is particularly close to a different form of Swahili than the one in Kenya and Tanzania. Though we failed to identify Comorian with Swahili, we did identify Tajik with Persian (Farsi), Afrikaner with Dutch, Macedonian with Bulgarian, Turkmen and Azerbaijani with Turkish, Belarusian with Russian, and Icelandic with Danish. Finally, since the table is limited to values of .04 and over, it is worth recalling that languages that appear in the CSP column but not in the CNP column may still be in our databank with a value below .04. 


\section{Appendix 2}

Total Trade and Rauch categories (yearly estimates)

Table A2a: total trade

\begin{tabular}{|c|c|c|c|c|c|c|c|c|c|c|}
\hline & 1998 & 1999 & 2000 & 2001 & 2002 & 2003 & 2004 & 2005 & 2006 & 2007 \\
\hline Distance $(\log )$ & $\begin{array}{l}-1.300 \\
(-56.538)\end{array}$ & $\begin{array}{l}-1.329 \\
(-60.814)\end{array}$ & $\begin{array}{l}-1.341 \\
(-64.291)\end{array}$ & $\begin{array}{l}-1.335 \\
(-64.127)\end{array}$ & $\begin{array}{l}-1.370 \\
(-65.856)\end{array}$ & $\begin{array}{l}-1.390 \\
(-68.171)\end{array}$ & $\begin{array}{l}-1.373 \\
(-66.331)\end{array}$ & $\begin{array}{l}-1.394 \\
(-68.280)\end{array}$ & $\begin{array}{l}-1.391 \\
(-68.174)\end{array}$ & $\begin{array}{l}-1.371 \\
(-65.701)\end{array}$ \\
\hline Common border & $\begin{array}{l}0.711 \\
(6.829)\end{array}$ & $\begin{array}{l}0.707 \\
(7.088)\end{array}$ & $\begin{array}{l}0.737 \\
(8.086)\end{array}$ & $\begin{array}{l}0.691 \\
(7.386)\end{array}$ & $\begin{array}{l}0.597 \\
(6.051)\end{array}$ & $\begin{array}{l}0.736 \\
(7.256)\end{array}$ & $\begin{array}{l}0.675 \\
(6.687)\end{array}$ & $\begin{array}{l}0.747 \\
(7.511)\end{array}$ & $\begin{array}{l}0.681 \\
(6.624)\end{array}$ & $\begin{array}{l}0.651 \\
(6.058)\end{array}$ \\
\hline Ex colonizer/colony & $\begin{array}{l}1.835 \\
(16.465)\end{array}$ & $\begin{array}{l}1.712 \\
(15.221)\end{array}$ & $\begin{array}{l}1.654 \\
(14.908)\end{array}$ & $\begin{array}{l}1.575 \\
(13.740)\end{array}$ & $\begin{array}{l}1.645 \\
(14.418)\end{array}$ & $\begin{array}{l}1.644 \\
(14.387)\end{array}$ & $\begin{array}{l}1.557 \\
(13.194)\end{array}$ & $\begin{array}{l}1.577 \\
(13.589)\end{array}$ & $\begin{array}{l}1.583 \\
(14.449)\end{array}$ & $\begin{array}{l}1.468 \\
(12.820)\end{array}$ \\
\hline Common religion & $\begin{array}{l}0.326 \\
(4.237)\end{array}$ & $\begin{array}{l}0.333 \\
(4.479)\end{array}$ & $\begin{array}{l}0.215 \\
(2.956)\end{array}$ & $\begin{array}{l}0.261 \\
(3.647)\end{array}$ & $\begin{array}{l}0.259 \\
(3.753)\end{array}$ & $\begin{array}{l}0.362 \\
(5.244)\end{array}$ & $\begin{array}{l}0.312 \\
(4.529)\end{array}$ & $\begin{array}{l}0.326 \\
(4.749)\end{array}$ & $\begin{array}{l}0.330 \\
(4.850)\end{array}$ & $\begin{array}{l}0.390 \\
(5.598)\end{array}$ \\
\hline Common legal system & $\begin{array}{l}0.197 \\
(3.745)\end{array}$ & $\begin{array}{l}0.192 \\
(3.799)\end{array}$ & $\begin{array}{l}0.206 \\
(4.206)\end{array}$ & $\begin{array}{l}0.215 \\
(4.368)\end{array}$ & $\begin{array}{l}0.206 \\
(4.281)\end{array}$ & $\begin{array}{l}0.236 \\
(4.924)\end{array}$ & $\begin{array}{l}0.275 \\
(5.749)\end{array}$ & $\begin{array}{l}0.217 \\
(4.608)\end{array}$ & $\begin{array}{l}0.210 \\
(4.494)\end{array}$ & $\begin{array}{l}0.283 \\
(5.986)\end{array}$ \\
\hline
\end{tabular}

All regressions contain exporter and importer fixed effects. Student ts are in parentheses. These are based on robust standard errors. 
Table A2b: homogeneous goods

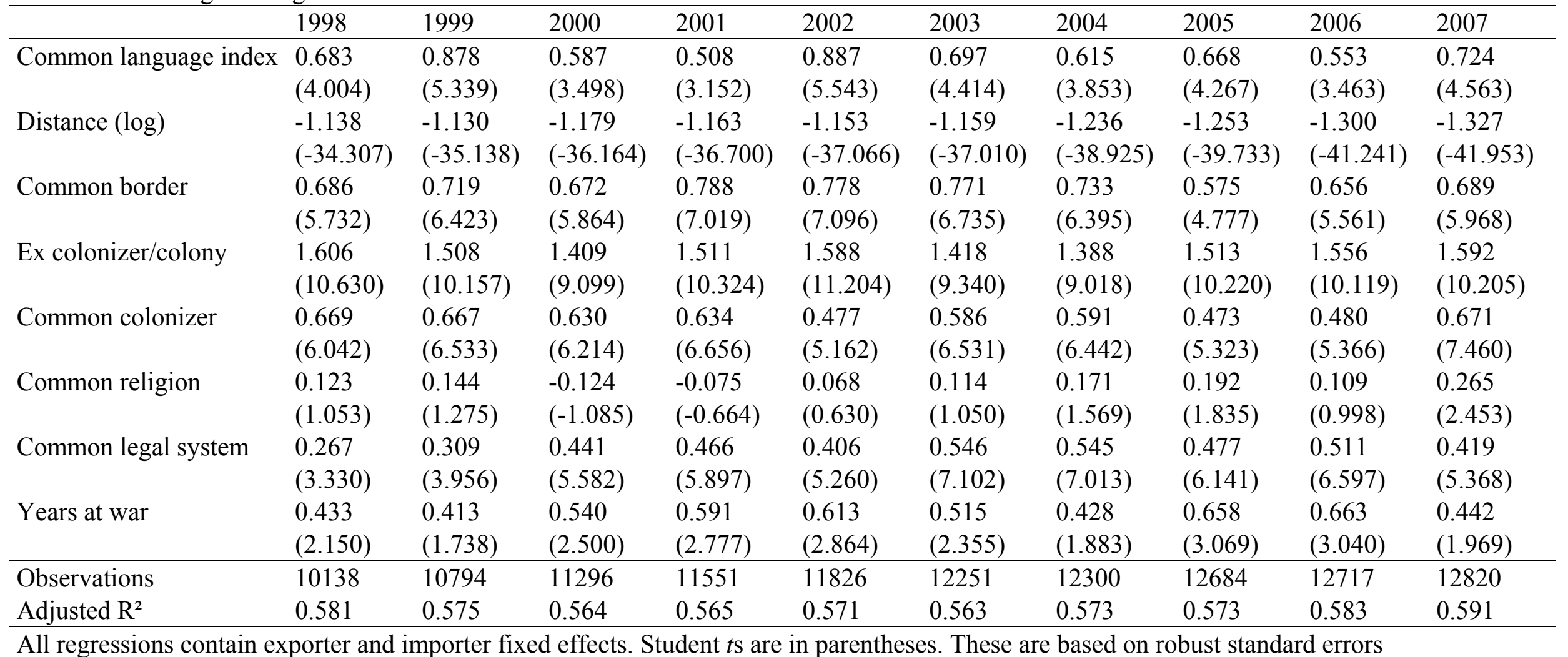


Table A2c: listed goods

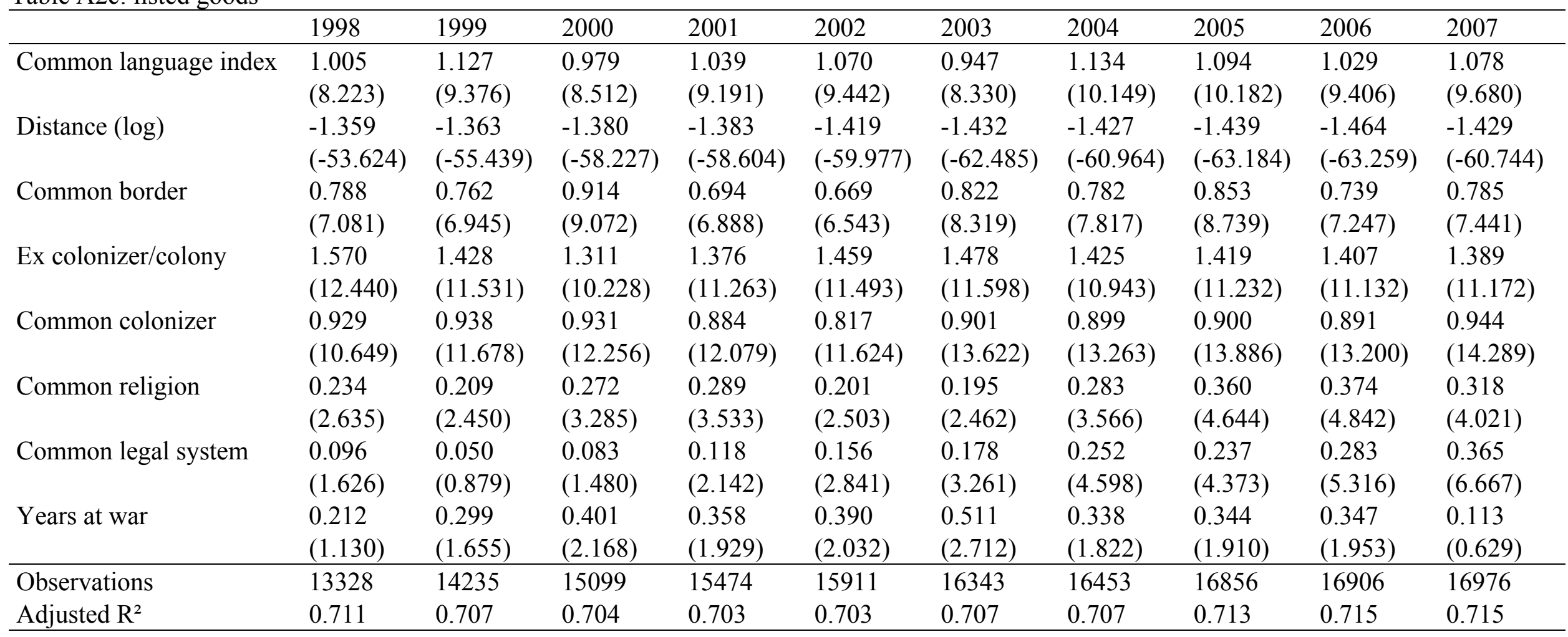

All regressions contain exporter and importer fixed effects. Student $t$ s are in parentheses. These are based on robust standard errors 
Table A2d: differentiated goods

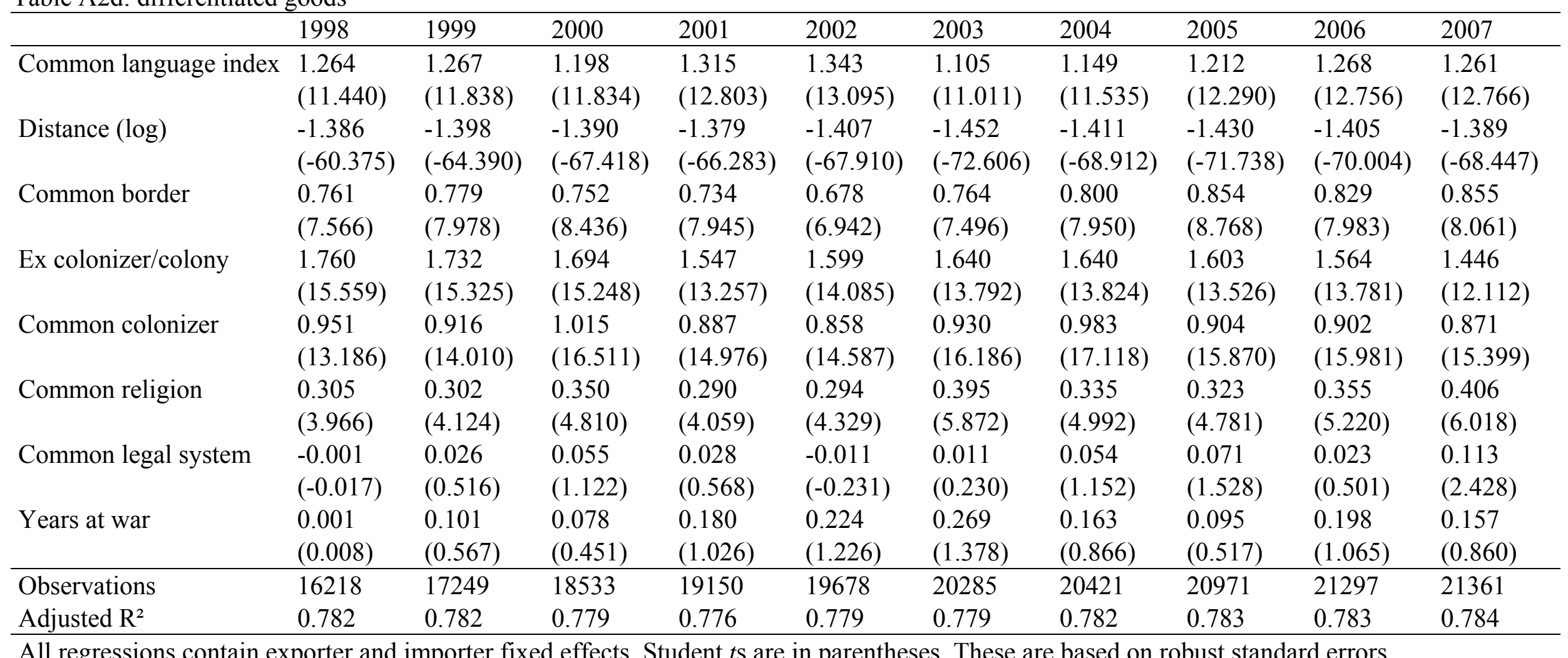


One possible problem in our study is selection bias. Suppose that the influence of language in our estimates depended on our automatic exclusion of the zeros through our choice of a loglinear specification. In effect, this would mean that language has virtually no role in explaining the zeros and is only significant because we drop them.

As a response, we can select the countries in our sample on the basis of size of GNP instead. It so happens (though it need not have) that the countries with the 50 largest GNPs trade with nearly all of the other 49 . Of the 24,500 possible observations, 24,312 remain, and the zeros constitute less than $1 \%$. There are therefore few zeros quite independently of our choice of a log-linear specification. If language is strictly significant for positive trade values, language will still remain significant in our tests. However, if instead language does play a role in explaining the zeros, the coefficient of language might be expected to fall though remaining significant. The reason is that the trade values for the 50 largest countries are much higher on average than in the complete sample. Therefore, any fixed costs resulting from linguistic frictions would play a smaller relative role. Those fixed costs might be expected to fall in proportion to trade as trade values rise. We might therefore expect lower coefficients of language to follow.

The results are in Table A3. The coefficients of COL, CSL and CNL indeed fall though remaining highly significant. They also retain the same relative order as before. Once the three variables appear together, with or without LP, though, they are no longer simultaneously significant. This is not surprising since the variance of the linguistic factors, on which we depend in order to be able to identify three, if not four, separate linguistic influences at once, is now much lower than before in the individual-year estimates (and therefore also in the panel estimates). Notwithstanding, the one linguistic influence that remains significant at the .05 confidence level or close to it is CSL, in conformity with our analysis. There is nothing here to comfort the idea that by choosing a specification that automatically drops the zeros, we fortify the impact of language. 
Table A3: Using the $\mathbf{5 0}$ largest countries

\begin{tabular}{|c|c|c|c|c|c|c|c|c|}
\hline & $(1)$ & $(2)$ & (3) & (4) & $(5)$ & $(6)$ & $(7)$ & $(8)$ \\
\hline \multirow{2}{*}{$\begin{array}{l}\text { Common official } \\
\text { language }\end{array}$} & 0.361 & & & & 0.181 & 0.156 & 0.156 & 0.228 \\
\hline & $(3.514)$ & & & & $(1.290)$ & $(1.101)$ & $(1.116)$ & $(1.633)$ \\
\hline Common spoken language & & $\begin{array}{l}0.539 \\
(4.547)\end{array}$ & & & $\begin{array}{l}0.286 \\
(1.707)\end{array}$ & $\begin{array}{l}0.386 \\
(2.035)\end{array}$ & $\begin{array}{l}0.398 \\
(1.903)\end{array}$ & \\
\hline Common native language & & & $\begin{array}{l}0.701 \\
(4.485)\end{array}$ & & $\begin{array}{l}0.215 \\
(0.809)\end{array}$ & $\begin{array}{l}0.026 \\
(0.084)\end{array}$ & $\begin{array}{l}0.031 \\
(0.089)\end{array}$ & $\begin{array}{l}0.426 \\
(1.719)\end{array}$ \\
\hline Common native language $\mathrm{d}$ & lummy & & & $\begin{array}{l}0.613 \\
(4.407)\end{array}$ & & & & \\
\hline Linguistic proximity (tree) & & & & & & $\begin{array}{l}-0.039 \\
(-1.232)\end{array}$ & & \\
\hline Linguistic proximity (ASJP & & & & & & & $\begin{array}{l}-0.046 \\
(-0.981)\end{array}$ & $\begin{array}{l}-0.007 \\
(-0.178)\end{array}$ \\
\hline Distance $(\log )$ & $\begin{array}{l}-1.031 \\
(-28.654)\end{array}$ & $\begin{array}{l}-1.003 \\
(-27.275)\end{array}$ & $\begin{array}{l}-1.026 \\
(-28.791)\end{array}$ & $\begin{array}{l}-1.028 \\
(-28.620)\end{array}$ & $\begin{array}{l}-1.012 \\
(-27.433)\end{array}$ & $\begin{array}{l}-1.016 \\
(-27.428)\end{array}$ & $\begin{array}{l}-1.014 \\
(-27.540)\end{array}$ & $\begin{array}{l}-1.027 \\
(-28.688)\end{array}$ \\
\hline Common border & $\begin{array}{l}0.015 \\
(0.114)\end{array}$ & $\begin{array}{l}0.018 \\
(0.139)\end{array}$ & $\begin{array}{l}0.016 \\
(0.128)\end{array}$ & $\begin{array}{l}0.019 \\
(0.152)\end{array}$ & $\begin{array}{l}-0.002 \\
(-0.015)\end{array}$ & $\begin{array}{l}0.007 \\
(0.054)\end{array}$ & $\begin{array}{l}0.008 \\
(0.060)\end{array}$ & $\begin{array}{l}0.003 \\
(0.023)\end{array}$ \\
\hline Ex colonizer/colony & $\begin{array}{l}0.454 \\
(2.034)\end{array}$ & $\begin{array}{l}0.551 \\
(2.447)\end{array}$ & $\begin{array}{l}0.607 \\
(2.586)\end{array}$ & $\begin{array}{l}0.615 \\
(2.613)\end{array}$ & $\begin{array}{l}0.513 \\
(2.241)\end{array}$ & $\begin{array}{l}0.501 \\
(2.202)\end{array}$ & $\begin{array}{l}0.502 \\
(2.197)\end{array}$ & $\begin{array}{l}0.518 \\
(2.235)\end{array}$ \\
\hline Common colonizer & $\begin{array}{l}-0.316 \\
(-1.078)\end{array}$ & $\begin{array}{l}-0.281 \\
(-0.940)\end{array}$ & $\begin{array}{l}-0.276 \\
(-0.915)\end{array}$ & $\begin{array}{l}-0.278 \\
(-0.930)\end{array}$ & $\begin{array}{l}-0.280 \\
(-0.941)\end{array}$ & $\begin{array}{l}-0.277 \\
(-0.929)\end{array}$ & $\begin{array}{l}-0.276 \\
(-0.929)\end{array}$ & $\begin{array}{l}-0.287 \\
(-0.965)\end{array}$ \\
\hline Common religion & $\begin{array}{l}0.349 \\
(3.225)\end{array}$ & $\begin{array}{l}0.273 \\
(2.486)\end{array}$ & $\begin{array}{l}0.308 \\
(2.874)\end{array}$ & $\begin{array}{l}0.295 \\
(2.742)\end{array}$ & $\begin{array}{l}0.282 \\
(2.579)\end{array}$ & $\begin{array}{l}0.322 \\
(2.847)\end{array}$ & $\begin{array}{l}0.307 \\
(2.733)\end{array}$ & $\begin{array}{l}0.318 \\
(2.834)\end{array}$ \\
\hline Common legal system & $\begin{array}{l}0.354 \\
(4.626)\end{array}$ & $\begin{array}{l}0.438 \\
(6.395)\end{array}$ & $\begin{array}{l}0.373 \\
(5.018)\end{array}$ & $\begin{array}{l}0.379 \\
(5.173)\end{array}$ & $\begin{array}{l}0.366 \\
(4.602)\end{array}$ & $\begin{array}{l}0.390 \\
(4.830)\end{array}$ & $\begin{array}{l}0.384 \\
(4.781)\end{array}$ & $\begin{array}{l}0.337 \\
(4.402)\end{array}$ \\
\hline Years at war & $\begin{array}{l}-0.050 \\
(-0.309)\end{array}$ & $\begin{array}{l}-0.057 \\
(-0.359)\end{array}$ & $\begin{array}{l}-0.044 \\
(-0.277)\end{array}$ & $\begin{array}{l}-0.044 \\
(-0.281)\end{array}$ & $\begin{array}{l}-0.042 \\
(-0.263)\end{array}$ & $\begin{array}{l}-0.052 \\
(-0.330)\end{array}$ & $\begin{array}{l}-0.049 \\
(-0.305)\end{array}$ & $\begin{array}{l}-0.039 \\
(-0.246)\end{array}$ \\
\hline Observations & 24312 & 24312 & 24312 & 24312 & 24312 & 24312 & 24312 & 24312 \\
\hline Adjusted $\mathrm{R}^{2}$ & 0.798 & 0.798 & 0.798 & 0.798 & 0.798 & 0.798 & 0.798 & 0.798 \\
\hline Number of clusters & 2450 & 2450 & 2450 & 2450 & 2450 & 2450 & 2450 & 2450 \\
\hline
\end{tabular}

